\title{
Leasing Indian Water Off the Reservation: A Use Consistent With the Reservation's Purpose
}

\begin{abstract}
The extent of permissible Indian water use in the United States is determined by the Indian "reserved rights" doctrine, pronounced in Winters v. United States. The Supreme Court there ruled that Indian water rights were impliedly reserved at the time of the reservation's creation for the benefit of the Indians, and for a use necessary to fulfill the purpose of the reservation. Unfortunately, the Court offered little guidance for defining the purpose of an Indian reservation. Consequently, courts can, and have, erred in determining the permissible extent of Indian water uses. While both current law and policy support on-reservation leasing of Indian water to non-Indians, debate continues over whether off-reservation leases would be consistent with the purpose of the reservation. This Comment proposes guidelines for ascertaining the permissible uses of Indian water rights. Based on congressional intent, these guidelines and the underlying policy rationales make it clear that off-reservation leasing of Indian water rights is a use consistent with the purpose of the reservation and thus permissible under the Indian reserved water rights doctrine.
\end{abstract}

\section{INTRODUCTION}

Benjamm Franklin observed that we only know the worth of water when the well runs dry. ${ }^{1}$ Energy development, the growth of urban centers, agriculture, grazing lands, and essentially all human activity and development depend upon pure water resources. While vast water reclamation projects green the thirsty environment of the western United States, ${ }^{2}$ water has been-and always will be-the critical limiting factor in the arid or semiarid regions of the West. ${ }^{3}$ Those with access to water supphes have wealth, power, and a vital ingredient of life.

Extraordimary competition currently exists in the western United

1. J. Bartlett, Familiar QuOTATIONS 347 (150th Anniversary ed. 1980).

2. WATER INFormation Center, INC., Water ATLAS OF THE UNITEd States, plate 15 (1973) [hereinafter WATER ATLAS] ("The importance of water transfers is made evident by the fact that one out of every five persons in the Western States is served by a water supply system that imports from a source 100 miles or more away.")

3. See Shipek, Effects of Drastic Water Loss on Native American Reservations, in INDIAN SIA: The Social Impact Assessment of Rapid Resource Development on Native Peoples 166 (1982); see also Western States Water Council, Paper No. 3, Report on INDiAN WATER RIGHT CASES IN THE ELEVEN Western States (C. Geisler ed. 1976) (discussing effects of water shortage on American Indians). The dry climate of the West "extend[s] from western Minnesota southward to the Gulf of Mexico," or roughly west of the 100th meridian. WATER ATLAS, supra note 2, plate 15. 
States between the users of federally reserved water rights and state water appropriations ${ }^{4}$ for the scarce supply of usable surface and ground water. ${ }^{5}$ The coinpetition has intensified as water demand has increased for expanding metropolitan areas and for expanding energy and inineral resource development. At present, there is insufficient water to fulfill simultaneously the national coinmitment to honor federal reserved water rights, the water needs of junior priority users, and additional demands created by new users. ${ }^{6}$

At the heart of this "water war" is the controversial Indian "reserved rights" doctrine established in Winters $v$. United States ${ }^{7}$ and reinforced in Arizona v. California. ${ }^{8}$ The concept of Indian reserved water rights has recently been the subject of intense criticisn debate. ${ }^{9}$ The Winters, reserved rights doctrine, has generated contro-

4. State appropriation rights are subject to the requirements of continual, beneficial use, and priority according to the time of first diversion. Federal reserved rights are based on federal law and exist to fulfill the purposes of a federal reservation. They are not lost by nonusc. See infra notes 35 41 and accompanying text.

5. The importance and scarcity of water in the Southwest was specifically noted by the Supreme Court in Colorado River Water Conservation Dist. v. United States, 424 U.S. 800, 804 (1976) ("It is probable that no problem of the Southwest section of the Nation is more critical than that of scarcity of water. As southwestern populations have grown, conflicting claims to this scarce resource have increased."); see NATIONAL WATER COMMISSION, WATER POLICIES FOR THE

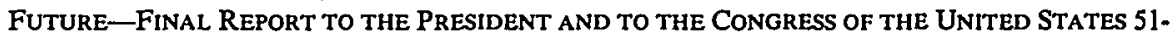
61 (1973) [hereinafter Water Policies]; Public LANd LAW Review CoMM'N, ONe ThiRd of THE NATION'S LAND 141-55 (1970).

6. Most authorities agree that there will be a future water shortage in the West, most likely in the Colorado River water basin arca. See, e.g., THE COMPTROller of THE UNITED STATES, Report to Congress, Colorado River Basin Water Problems: How to Reduce Their IMPACT 6 (1979) [hereinafter Colorado River Basin Problems]; T. ANDERSON, Water Crisis: ENding the Policy Drought 1-4 (1983); Water Resources Council, Water

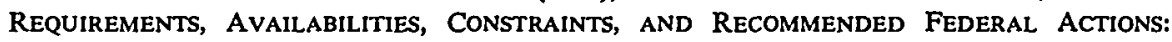
Project INDEPENDENCE II-4, V (1974). The Colorado Basin consists of 254,500 square miles drained by the Colorado River-approximately one-twelfth of the entire area of the United States, excluding Alaska. Id. at IV-78, IV-88.

7. 207 U.S. 564 (1908).

8. 373 U.S. 546 (1963).

9. See, e.g., Comptroller General of the Untted States, Report to Congress, RESERVED WATER RIGHTS FOR FEDERAL AND INDIAN RESERVATIONS: A Growing CONTROVERSY IN NEED OF RESOlution (1978) (examining the controversial questions and issues surrounding Indian reserved water rights, and urges Congress to resolve them); $R$. ForEMAN, INDIAN Water Rights: A PUblic POLICY ANd Administrative Mess (1981) (discussing how interests in western water supplies are polarized and complicated due to federal indian water policy and water management practices); Bloom, Indian "Paramount" Rights to Water Use, 16 RockY MTN. MIN. L. INST. 669 (1971) (identifying current chaos and uncertainty over 1ndian water rights and urges general adjudication to provide clarity and finality); Clyde, Special Considerations Involving Indian Rights, 8 NAT. RESOURCES LAw. 237 (1975) (arguing that the use of Indian reserved rights will wreak havoc upon existing state economies); Hundley, The "Winters" Decision and Indian Water Rights: A Mystery Reexamined, 13 W. HIST. Q. 17 (1982) (researching history surrounding Winters in an attempt to clarify the uncertainties created); Pelcyger, Indian Water Rights: Some Emerging Frontiers, 21 Rocky MTN. MiN. L. 1NST. 743 (1975) (expressing the hostility of states toward Indian reserved rights); Ranquist, The Winters Doctrine and How It Grew: 
versy by allowing tribes to claim water that had previously been appropriated by non-Indian water users under state law. ${ }^{10}$ The extent of Indian water claims remains largely unquantified, ${ }^{11}$ yet it is substantial, smce these claims are determined by the number of practicably irrigable acres $^{12}$ available to satisfy the present and future needs of Indians who live on reservations in the United States. ${ }^{13}$ Thus, Indian claims have enormous potential to disrupt existimg patterns of western water use. ${ }^{14}$ The National Water Commission commented on the conflict, stating:

[I] $\mathrm{n}$ the water-short West, billions of dollars have been invested in water resource projects benefitting non-Indians but using water in which the Indians have a priority of right if they choose to develop water projects of their own in the future. In short, the nation faces a conflict between the right of Indians to develop their long-neglected water resources and the

Federal Reservations of Rights to the Use of Water, 1975 B.Y.U. L. REV. 639 (urging the adoption of an administrative mechanism to resolve conflicts over federally reserved rights).

10. McCool, Indian Water Rights, The Central Arizona Project and Water Policy in the Lower Colorado River Basin, 2 J. ENERGY L. \& POL'Y 107, 108 (1981).

11. One reason why the majority of Indian reserved water rights remain unquantified is that, until recently, there was no siugle forum available in which all the rights to the use of water in a river system could be adjudicated. Until 1952, the doctrine of sovereign immunity protected the federal government aud the tribes from being sued without their consent. That year Congress passed the McCarran Amendment, which waived the sovereign immunity of the United States in cases involving the water rights in a river system, "where it appears that the United States is the owner of or is in the process of acquiring water rights by appropriation under State law, by purchase, by exchange, or otherwise, and the United States is a necessary party to such suit." 43 U.S.C. $§ 666$ (1982). The amendment thus removed a severe limitation on the ability of states to adjudicate all potential rights to a water source. The Supreme Court subsequently held that the McCarran Amendment applies to Indian lands aud Indian water rights. See Colorado River Water Conservation Dist. v. United States, 424 U.S. 800 (1976) (dismissing a federal suit in favor of concurrent jurisdiction in a Colorado state court); see also Arizona v. San Carlos Apache Tribe, 463 U.S. 545 (1983) (holding that Colorado River applies equally to suits brought by private parties and states). Colorado River, San Carlos Apache, and the McCarran Amendment have crcated enormous controversy over whether state courts are the proper forum, from a public policy perspective, for adjudicating Indian water rights. See infra note 103 and accompanying text. The likely restrictive interpretation of Indian water rights in state courts, and the high cost and time involved in litigation, have led the tribes, state planners, and federal officials to attempt to settle Indian water rights by agreement. See Fort Peck-Montana Compact of May 12, 1985; Ak-Chin Water Settlement Act of 1978, Pub. L. No. 95-328, 92 Stat. 409 (1978); Buffalo Bill Dam: Reclamation Reform Act of 1982, Pub. L. No. 97-293, tit. III, 96 Stat. 1261, 1274-85 (1982) (regarding Papago Indian water rights).

12. The "practicably irrigable" acreage standard was first pronounced in Arizona v. California, 373 U.S. at 546, 601, as a means of quantifying Indian reserved rights for five Colorado River tribes. See infra text accompanying notes 63-65.

13. See Arizona v. California, 373 U.S. 546, 600 (1963).

14. More than half of all reservation land and the majority of the reservation population are located in the driest areas of the western United States. See Hundley, supra note 9, at 17; see also Shrago, Emerging Indian Water Rights: An Analysis of Recent Judicial and Legislative Developments, 26 Rocky MTN. MIN. L. INST. 1105 (1980), where the author calculates that:

In Arizona, . . . where there are approximately 19.4 million acres of Indian land, the practicably irrigable acreage test would ostensibly entitle the Indian tribes to more than ten times the amount of the annual dependable supply of water in the state even if only onethird of the reservation lands are "practicably irrigable."

Id. at 1116 (footnote omitted). 
impairment of enormous capital investments already made by nonIndians in the same water supply. ${ }^{15}$

Consequently, Indian water claims have incited hostility among nonIndian water users as "states and their voters, wary of the assertion of Indian interests, are beginning to take a narrower view of [reserved] rights."16

Unfortunately, the Supreine Court has provided little guidance which might resolve these conflicts. The Winters Court merely recognized Indian reserved water rights, leaving unresolved the extent of the right and the inanner in which it may be used. This ambiguity has produced inconsistencies in law and policy concerning the use of Indian water on and off the reservation. ${ }^{17}$ For example, current law and policy permit tribes to lease their lands and water to non-Indians for a variety of on-reservation uses, ${ }^{18}$ but it remains unclear whether tribes may lease

15. Water Policies, supra note 5, at 476.

16. Note, State Jurisdiction to Adjudicate Indian Reserved Water Rights, 18 NAT. Resources J. 221, 228 (1978). The authors cite a recent recommendation by the Western Conference of the Council of State Governments that would "prohibit Indians from voting in state eleetions unless they surrender jurisdiction over their lands and persons to the states." Id. at 228-29. Another commentator has written that several organizations, including the Interstate Congress for Equal Rights and Responsibilities and Montanans Opposed to Discrimination, have "formed to lobby for abrogation of Indian rights." Clinton, Isolated in Their Own Country: A Defense of Federal Protection of Indian Autonomy and Self-Government, 33 STAN. L. REv. 979, 980-81 (1981). For example, the Native Americans Equal Opportumity Act, H.R. 13329, 95th Cong., 2d Sess. (1978), would have directed the President to:

[A]brogate within a year all treaties with the Indians; to terminate federal supervision over the property and rights of Indian tribes; to fully subject Indians to state jurisdiction; to compel tribes to distribute certain tribal assets per capita to their members; and to progressively eliminate the restraints on alienation and the tax immunities presently applied to tribal lands.

Clinton, supra, at 981. See generally Pelcyger, Indian Water Rights: Some Emerging Frontiers, 21 Rocky MTN. MIN. L. INST. 743, 745-51 (1975) (discussing recent court adjudications and trends indicative of state hostilities toward Indians and their property rights). See also supra notes 139-41 and accompanyimg text (discussing the United States' termination policy).

Moreover, Indian water rights are potentially much more extensive than other federally reserved rights that provide benefits to non-Indians. Dissenting in Arizona v. San Carlos Apaehc Tribe, 463 U.S. 545 (1983), Justice Stevens notes that " 'Indian reserved water rights present a more pressing problem than Federal reserved water rights. Unlike Federal reservations, which are not expected to have large consumptive water demands, many Indian reservations are expected to require significant water quantities to satisfy reservation purposes." " Id. at $575 \mathrm{n} .5$ (Stevens, J., dissenting) (quoting CoMpTroller GENERAL OF THE U.S., RESERVED WATER RIGHTS FOR FEDeral and INDIAN Reservations: A Growing Controversy in NeEd of Resolution 18 (1978)). Furthermore, unlike Indian reservations, national forests, national parks, and other federal uses provide benefits such as lumbering operations, grazing, recreational purposes, watershed protection, and tourist revenues to non-Indian residents.

17. See infra Part III.

18. Tribal lands and related water can be leased by non-Indians upon the approval of the Secretary of the Interior. 25 U.S.C. $\$ 415$ (1982). Since the leasing statute was enacted, more than 50 million acres of Indian trust land have been leased to non-Indians for a multitude of purposes. Chambers \& Price, Regulating Sovereignty: Secretarial Discretion and the Leasing of Indian Lands, 26 STAN. L. REv. 1061, 1062 \& n.5 (1974). The statute provides that land may be leased for 
their water rights to outsiders for off-reservation use. Some commentators beheve that off-reservation leases would undermine Congress' purpose of preserving the agricultural character of the reservation. ${ }^{19}$ Others claim that such leases are an effective way to promote the purpose of tribal self-sufficiency. ${ }^{20}$ The Supreme Court has yet to rule on whether off-reservation leasing of Indian water rights is a permissable use of those rights.

Even though some courts and commentators have sought to define the extent and ultimate use of an Indian water right, ${ }^{21}$ confusion remaims. Judgments concerning the scope of Indian water uses must be made in hight of the purposes behind the creation of Indian reservations. ${ }^{22}$ Without a clear understanding of the reservation's purpose, courts can, and have, erred in ascertaining the proper extent of Indian water uses. ${ }^{23}$ Moreover, since the treaties that created reservations seldom, if ever, contemplated Indian water use, ${ }^{24}$ the lack of a clear defimition of the reservation's purpose only serves to promote uncertainty. In response to this problein, this Comment seeks to illuminate the general purpose for creating Indian reservations, and to give apphicable guidelines for determining the extent of Indian water uses. ${ }^{25}$ This Comment concludes that

"public, religious, educational, recreational, residential, or business" uses, and since section 415 allows for the "development or utilization of natural resources in connection with . . . such leases," a wide variety of on-reservation related water uses are allowed.

Moreover, case law permits transfers of the "full" amount of reserved water rights of an Indian allottec to a non-Indian purchaser. See United States v. Power, 305 U.S. 527, 532 (1939) (some portion of the right to use tribal waters passes to owner of alloted lands); Colville Confederated Tribes v. Walton, 647 F. 2d 42, 51 (9th Cir.) (allottee can transfer full reserved right to non-Indian), cert. denied, 454 U.S. 1092 (1981); Skeem v. United States, 273 F. 93, 96 (9th Cir. 1921) ("water ... permanently reserved for the tracts which the Indians chose not to relinquish" and "the actual leasing of their lands ... [did not] operate[] to relinquish any water rights in the lands which they so chose to retain"); United States ex rel Ray v. Hibner, 27 F. 2d 909 (D. Idaho 1928) (amount transferred is determined by beneficial use).

Nevertheless, although 25 U.S.C. $\$ 415$ (1982) allows for a limited exception to the requirement of congressional approval for the leasing of Indian lands and related water uses, the exception does not expressly permit the transfer of water as a natural resource independent of the tribal lands. Moreover, Congress has not enacted a statute that would expressly permit such transfers, although the National Water Commission has urged it to do so. See WATER Policies, infra note 5, at 48081. In fact, any conveyance of Indian land or water rights separable from the land would require congressional approval as dictated by the Nonintercourse Act, 25 U.S.C. $§ 177$ (1982). See supra note 208 and accompanying text.

19. See infra notes $156-58$ and accompanying text.

20. See infra notes $220-25$ and accompanying text.

21. See eases discussed infra in notes 7-16 and accompanying text.

22. See infra text following note 80 .

23. Id.

24. See infra text accompanying note 80 .

25. This Comment does not propose to construct a general definition of a reservation's purpose applicable to all Indian reservations. The author recognizes that each treaty was uniquely negotiated by the United States government and the Indian tribes. This Comment rather seeks to provide general guidelines based on the historical policies and intent of Congress in creating and maintaining 
leasing Indian water rights to non-Indians for off-reservation use is consistent with the purpose of the reservation. Off-reservation leasing of Indian water rights, in fact, will benefit both Indians and non-Indians alike.

Part I of this Comment describes the origins of the tension between the reserved rights doctrine and other doctrines. It begins by discussing the sources of the various water law doctrines currently used in the United States. It then reviews the major water law cases which estabhshed Indian water rights and highlights the courts' interpretations of the reservation's purpose. Where appropriate, this Section discusses how ambiguity in the courts' language created uncertainty over the proper scope and ultimate uses of an Indian water right. Part I concludes by examining an erroneous analysis of Indian water rights claims in a recent state court adjudication. ${ }^{26}$ This case demonstrates the need both for understanding the general purpose of an Indian reservation, and for uniforn guidehines to determine the pernnissible uses of the reserved right.

Part II of this Comment offers guidelines for deterinining whether a particular Indian water use is consistent with the reservation's purpose. These guidelines are derived front the congressional intent behind creating and maintaining reservations. Part II therefore examines the history of Federal-Indian relations that led to the establishment and maintenance of Indian reservations. Finally, Part III applies the previous Section's conclusions to resolve the issue of whether leasing Indian water for off-reservation use is perinissible under the reserved rights doctrine. Part III then discusses the case law, legal bars, and policy debate concerning Indian water leases, and also explores the resulting cultural inplications for tribes should they choose to lease their water to non-Indians for use either on or off the reservation.

I

\section{THE NEED For GUIDELINES}

\section{A. Water Law Doctrines}

Contemporary water law in the United States has developed primarily from local custom or common law. ${ }^{27}$ As a result, the water law doctrines adopted by various states and the federal government often conflict both in theory and in practice. In regions where water demand exceeds its supply, conflicts in water law doctrines have created substantial controversy over who can use the water, when and how the water can be

Indian reservations. Such guidelines serve to define more accurately the permissible scope of Indian water uses.

26. In re General Adjudication of All Rights to Use Water in the Big Horn River System, 753 P.2d 76 (Wyo. 1988) [hereinafter Wind River].

27. T. Anderson, supra note 6 , at 26-30. 
used, and from what source the water can be taken. This Section briefly describes the basic water law doctrines and examines their fundamental differences. Specifically, this Section focuses on how Indian reserved rights dramatically conflict with the state appropriation laws.

Water law in the United States is characterized by three basic doctrines, commonly referred to as "riparian", "prior appropriation", and "reserved right". ${ }^{28}$ The riparian system of allocating water is generally used in the eastern states ${ }^{29}$ where water is readily available. ${ }^{30}$ Under the riparian system, each landowner abutting a stream is entitled to use the stream's flow, limited only by the equal rights of the other riparian owners. Thus, a landowner may insist that the stream remain in its natural condition. $^{31}$ A riparian owner need not put his water to beneficial use, ${ }^{32}$ nor can he lose his right by nonuse. ${ }^{33}$ Rather, the riparian right exists as an mcident to land ownership. In times of shortage, all riparian owners must reduce their water use on a pro rata basis. ${ }^{34}$

The western states generally follow the prior appropriation doctrine, which, as the name suggests, grants an earlier user priority over later users. $^{35}$ This "first come, first serve" method of allocating water was a result of early miming operations in the dry climate of the West. The miners found that the riparian doctrine created an unworkable system in places where a scarce water supply was needed for use several miles from the stream. ${ }^{36}$ In response, local custom developed which granted the first user a "semor" right to divert a reasonable amount of water, so long as he used it on a contmual basis. This doctrine has reached the modern era

28. Id. at 27; 1 W. Hutchins, WATER Rights LAWS IN THE NinETEEN WESTERN STATES 200-02 (1974).

29. T. ANDERSON, supra note 6, at 27. Riparian rights are also held by individuals in a few western states, complicating the appropriative water rights system. $1 \mathrm{~W}$. HuTCHINS, supra note 28, at 200-02.

30. WATER ATLAS, supra note 2, plate 15 .

31. See T. ANDERSON, supra note 6 , at $27 ; 1$ W. HuTchins, supra note 28 , at 158, 202.

32. The concept of "beneficial use" developed in areas where increased water demands met a limited water supply. In certain states, such as South Dakota, people are required to exercise their water rights in a manner "that is reasonable and useful and beneficial to the appropriator, and at the same time is consistent with the interests of the public ... in the best utilization of water supplies." S.D. CODIFIED LAwS ANN. $§ 46-1-6(6)$ (1983). Clearly, what is or is not a beneficial use depends upon the facts and circumstances of cach situation. For example, a use that is beneficial in an area where water is abundant may not be a reasonable beneficial use in an area or time of great scarcity. See Tulare Irrigation Dist. v. Lindsay-Strathmore Irrigation Dist., 3 Cal. 2d 489, 567, 45 P.2d 972, 1007 (1935).

33. See American Indian Lawyer Training Program, Indian Water Policy in a Changing Environment 25 (1982) [hereinafter Indian Water Policy]; see also $1 \mathrm{~W}$. HUTCHINS, supra note 28, at 158.

34. INDIAN WATER POLICY, supra note 33 , at $25 ; 1$ W. HUTCHINS, supra note 28 , at 158.

35. T. ANDERSON, supra note 6, at 30; 1 W. HuTCHINS, supra note 28, at 226, 488-89.

36. See Irwin v. Phillips, 5 Cal. 140, 147 (1855) (recognizing the local custom of water use in the miners' camps); see also T. ANDERSON, supra note 6, at 27-28; 1 W. HUTCHINS, supra note 28, at $169,526-27$. 
virtually intact. Today, a senior appropriator may claim his full right during times of shortage even at the expense of those who acquired a later right. Unlike riparian rights, appropriation rights can be lost by nonuse. $^{37}$

The Supreme Court has articulated a third doctrine-the reserved rights doctrine-that specifically governs Indian water rights. In Winters v. United States, ${ }^{38}$ the Supreme Court held that the United States impliedly reserved water rights for the Indians when it set aside lands for the benefit of Indian peoples in the 19 th century. ${ }^{39}$ Winters rights conflict with almost every aspect of western water law because they arise independent of the state law system and thus are not subject to the state requirements of beneficial use, priority according to time of diversion, or loss of right by nonuse. ${ }^{40}$ Since the majority of reservation lands are located in western states, ${ }^{41}$ Winters reserved rights most often conflict with state prior appropriation laws. Non-Indian water users have therefore sought the help of the judiciary to resolve Indian water claims.

\section{B. Judicial Attempts to Define Reserved Rights}

Few cases involving the nature of Indian water rights have been decided by the Umited States Supreme Court. ${ }^{42}$ Although these cases have been supplemented by a few Ninth Circuit Court of Appeals decisions, courts have offered little clear guidance for ascertaining what uses of Indian water rights are consistent with the purpose of an Indian reservation. Additionally, the courts have failed to provide a meaningful defimition of the reservations' purpose. Nevertheless, the cases provide clues to the reservations' purpose that suggest an appropriate standard for evaluating the validity of particular Indian water uses.

37. See generally $1 \mathrm{~W}$. Hutchins, supra note 28 , at $488-569$. State statutes usually fix the length of time during which a right may remain unused, without justification, before it is considered lost by forfeiture or abandonment. See, e.g., Wyo. STAT. § 41-3-401 (1985) (setting duration at five successive years).

38. 207 U.S. 564 (1908).

39. Id. at 577 .

40. Id. at 577-78.

41. For example, 19 Indian reservations are located in Arizona, comprising 20 million acres of land, or nearly $27 \%$ of that state. In Arizona, Indian water claims incite heated debate because Arizona's share of the Colorado River is restricted to 2.8 million acre feet, and a significant portion of this was held to be reserved for five Indian tribes. Arizona v. California, 373 U.S. 546, 595-96, 600-01 (1963); see INDIAN WATER POLICY, supra note 33, at 13.

42. See, e.g., Washington v. Fishing Vessel Ass'n, 443 U.S. 658 (1979); Arizona v. California, 373 U.S. 546 (1963); Alaska Pacific Fisheries v. United States, 248 U.S. 78 (1918); Winters v. United States, 207 U.S. 564 (1908).

The Supreme Court has heard cases involving the rights of Indian allottees to water on reservation lands, United States v. Powers, 305 U.S. 527 (1939), and cases involving jurisdictional and finality matters, such as Arizona v. San Carlos Apache Tribe, 463 U.S. 545 (1983), Nevada v. United States, 463 U.S. 110 (1983), and Arizona v. California, 460 U.S. 605 (1983). 


\section{United States Supreme Court Cases}

Winters $v$. United States ${ }^{43}$ is the cornerstone case of the Indian reserved rights doctrine. In Winters, the United States brought suit on behalf of the Gros Ventre and Assiniboine Tribes of the Fort Belknap Reservation in Montana, seeking to enjoin diversions of water from the Milk River by farmers who had settled upstream from the reservation. The settlers contended, among other claims, that because the West was opened to settlement by government initiative and invitation, ${ }^{44}$ and they had diverted water from the Milk River before any water was appropriated or diverted by the United States or the tribe, they therefore had the prior right under state appropriation law. ${ }^{45}$ The Court found, however, that the Indian water rights were paramount to state water appropriations. ${ }^{46}$ It recognized the conflict between the Indians' and settlers' claims, ${ }^{47}$ but stated that "that which makes for the retention of the waters [by the Indians] is of greater force than that which makes for their cession." 48 Specifically, the Court found that the Fort Belknap Treaty of 1888, which created the reservation, was "of greater force" than the investments made by the settlers.

The Winters Court noted that the treaty itself contained no express reservation of water. ${ }^{49}$ Thus, in determining whether water was implicitly reserved for the benefit of the Indians, the Court looked beyond the express treaty provisions and considered the intent of Congress and the purpose of the Indian reservation.

The reservation was a part of a very much larger tract which the Indians

43. 207 U.S. 564 (1908).

44. Many families were induced to settle in the West by various acts of Congress. Pursuant to the Homestead Act of 1862, ch. 75, § 1, 12 Stat. 392 (codified as amended at 43 U.S.C. $\$ \S 161-302$ (1982)), the Desert Land Act of 1877 , ch. 107, $\S 1,19$ Stat. 377 (codified as amended at 43 U.S.C. $\S \S 321-339$ (1982)), the Reclamation Act, ch. 1093, § 8, 32 Stat. 390 (1902) (codified as amended at 43 U.S.C. $\$ \S 372-616$ (1982)), and the Carey Act, ch. 301, § 4, 28 Stat. 422 (1894) (codified as amended at 43 U.S.C. $\$ \S 641-648$ (1982)) non-Indians settled lands and obtained water rights under state appropriation systems. See Wind River, supra note 26, 753 P.2d at 90 (discussing how settlers were induced to move west pursuant to federal policy).

45. Winters, 207 U.S. at $\mathbf{5 6 8 - 7 0 .}$

46. $I d$.

47. The settlers had contended:

If the claim of the United States and the Indians be maintained, the lands of the defendants and the other settlers will be rendered valueless, the said communities will be broken up and the purpose and object of the Government im opening said lands for settlement will be wholly defeated.

Winters, 207 U.S. at 570 . This argument has proved to be a recurring plea in water litigation. See, e.g., Wind River, supra note 26, 753 P.2d at 94-99; cf. Hundley, supra note 9, at 32 n.47 (noting media reports that Indians could irrigate an entire reservation "in preference to and regardless of the farmers who have invested their money and time in reclaiming the valley and building a prosperous community of homes").

48. Winters, 207 U.S. at 576.

49. Id. at 575 . 
had the right to occupy and use, and which was adequate for the habits and wants of a nomadic and uncivilized people. It was the policy of the government, it was the desire of the Indians, to change those habits and to become a pastoral and civilized people. ${ }^{50}$

The Court observed that such a change could not have been accomplished on "practically valueless" lands without the use of water.

Noting that the Indians had "command of the lands and the waters-command of all their beneficial use, whether kept for hunting, 'and grazing roving herds of stock,' or turned to agriculture and the arts of civilization,"52 Justice McKenna's majority opinion asked rhetorically, "Did they give up all this? Did they reduce the area of their occupation and give up the waters which made it valuable or adequate?"s3 The Court found it inconceivable that Congress "took froin [the Indians] the means of continuing their old habits, yet did not leave them the power to change to new ones." 54 Thus, by exainining congressional intent and the purposes of the reservation, the Court was able to conclude that water was reserved for the tribes' benefit, "and for a use which would be necessarily continued through the years." 55

Although not a clear-cut definition, the Winters Court does provide a few criteria for evaluating a reservation's purpose. The Court noted that on the Fort Belknap reservation, the Indians had a right to occupy and use the lands. The tribes were encouraged to change their nomadic habits and becoine a pastoral and civilized people. The Court also stated that the Indians retained their right to beneficially use the reservation for a variety of purposes, including the "arts of civilization."56 Yet the Court's analysis does not proceed to show how the tribes inight use the land and waters they cominand. For example, what exactly are the paraineters of becoming a civilized people and pursuing the arts of civilization? Are Indians limited by the sum of the nations' progress at the time of the Winters decision in 1908? Or are unforeseen water uses such

50. Id. at 576.

51. Id.

52. Id. (quoting Agreement with the Indians of the Fort Belknap Indian Reservation in Montana, reprinted in 1 LAws \& TREATIES 601 (1904)). The Court apparently believed that at the time the Fort Belknap Treaty was signed, an essential purpose of the reservation was to "civilize" the Indians through agricultural production. Id. This should not, however, be construed as a limitation on the scope of Indian treaty rights since it merely "conformed to the conventional wisdom of Americans in the late nineteenth and early twentieth centuries who believed that the plow offered the major route to civilization for Native Americans." Hundley, supra note 9, at 38. This idea is furthered by the fact that the government's allotment policy was in effect during the time the Fort Belknap treaty was executed and Winters was decided. See infra notes 125-33 and accompanying text.

53. Winters, 207 U.S. at 576.

54. Id. at 577 .

55. Id.

56. Id. at 576 . 
as the leasing of Indian water to non-Indians for off-reservation use permissible within the scope of Winters? The Court did, however, more thoroughly define the general purpose of an Indian reservation ten years later in Alaska Pacific Fisheries v. United States. ${ }^{57}$

In Alaska Pacific, the United States brought suit to enjoin the Alaska Pacific Fisheries corporation from maintaining an extensive fish trap in waters reserved for the Metlakahtla Indians. In determining whether the waters were actually reserved for the Indians, the Court stated that the reservation lands were set apart "for a recognized public purpose-that of safe-guarding and advancing a dependent Indian people dwelling within the United States." 58 The Court explicitly said that " $[t]$ he purpose of creating the reservation was to encourage, assist and protect the Indians in their effort to train themselves to habits of industry, become self-sustaining and advance to the ways of civilized life."59 The Court further noted that "the islands [were] a suitable location ... because the fishery adjacent to the shore would afford a primary means of subsistence and a promising opportunity for industrial and commercial development." 60

A common denominator in both Alaska Pacific and Winters is that one purpose of the reservation was to promote the "arts" or "ways" of civilized life. Exactly what these terms denote is unclear, yet it is evident that Indians were encouraged to adopt a more "American way of life."61 The Court expressly noted attributes such as becoming industrious, independent, and self-supporting. The Indians in Alaska Pacific traditionally were a fishing people and the Court expressly identified waters surrounding the reservation that would provide civilized opportunities, such as Indian industrial and commercial fishing. ${ }^{62}$ Similarly, the Indians in Winters were a nomadic people who originally hunted wild game. It was clear to the Winters Court that on a nuch smaller tract of reservation lands, the Indians would not be able to sustain themselves, or "advance in the ways of civilized life" by their "old habits" of hunting wild game. Hence, when the reservation was created, the Indians were encouraged to change to new habits by taking up agriculture and the arts of civilization instead. In both cases the reservation was created as a homeland for the Indians who were encouraged to develop an independent and productive tribal society advancing in the ways of civilized life. Whether the Indians used water for fishing, growing cash crops, or some other "art of civilization," the Court explicitly encouraged water uses

57. 248 U.S. 78 (1918).

58. Id. at 88 .

59. Id. at 89.

60. Id. at 88 .

61. See, e.g., Moore v. United States, 151 F.2d 760, 762 (9th Cir. 1946).

62. Alaska Pacific, 248 U.S. at 140. 
that would promote a common purpose, that of tribal economic self-sufficiency and the advancement of the American way of life.

A more recent Supreme Court case involved a dispute between five western states and the federal government on behalf of itself and five southwestern tribes. At issue in Arizona v. California ${ }^{63}$ was the extent of water claims in the lower Colorado River. In this case, the Court reaffirmed the principles underlying Winters and defined the manner for quantifying the amount of Indian water rights. The Court ruled that the Indians were entitled to sufficient water "to irrigate all practicably irrigable acreage on their reservations." ${ }^{44}$ Because only the extent of the right was at issue, the Supreme Court did not discuss the permissible uses to which the Indian water right may be put. Likewise, Special Master Rifkind in Arizona v. California specifically declined to examine whether the Court's method of quantifying an Indian reserved right restricted the reserved water solely to agricultural uses. Rather, the Special Master merely advised that "the measurement used in defining the magnitude of the water rights is the amount of water necessary for agriculture and

63. 373 U.S. 546 (1963). Prior to Arizona v. California, the Court had addressed the Winters doctrine in United States v. Powers, 305 U.S. 527 (1939). There the United States sought to stop all diversions of water by non-Indian purchasers of Indian land allotments on the Crow Indian reservation, arguing that the diversions impaired the water rights of the Crow. The non-Indian purchasers contended that they owned a portion of the water rights reserved for the prior Indian owners. The Court concluded that the right to use some portion of the tribal waters passed to the non-Indian owners, but it did "not consider the extent or precise nature of [the non-Indians'] rights in the waters." Id. at 533.

64. 373 U.S. at 600 . Arizona v. California was the first case to quantify the expected future water needs of Indians by using the "practicably irrigable acrcage" test. Unfortunately, the term was not precisely defined in the original case, although Special Master Tuttle defined practicably irrigable as "economically fcasible" when the case was later reopened. Report of Special Master Tuttle 94, Arizona v. California, 460 U.S. 605 (1983). In addition, the Special Master in Wind River identified practicably irrigable acreage as those acres susceptible to sustained irrigation at reasonable costs. Wind River, supra note 26, 753 P.2d at 100-12

These definitions can be problematic. An economic interpretation of the practicably irrigable acrcage standard makes quantification of Indian water rights dependent on the technical research of hydraulic and soil experts. Confiicting expert testimony that could result from relatively small changes in the interest rates, productivity assumptions, and crop selling prices might result in large changes in the amount of water awarded to a tribe. Note, Adjudication of Indian Water Rights Under the McCarran Amendment: Two Courts Are Better Than One, 71 GEO. L.J. 1023, 1054-55 \& n.252 (1983).

The practicably irrigable acreage standard itself may pose problems in certain situations. One such circumstance arises where a treaty expressly recognizes the importance of fishing to a tribe. In that case, water may be mcasured by practicably irrigable acreage and include additional water to maintain minimum instream fiows. A different problem arises where a reservation is not widely irrigable but could be a valuable source of minerals, lumber, fish, grazing lands, or hydroelectric power. Furthermore, a reservation located near an expanding metropolis may find anxious city developers wishing to lease valuable tribal water rights. See INDIAN WATER Policy, supra note 33, at 7; see also Brown, Conflicting Claims to Southwestern Water: The Equity and Management Issues, 1 Sw. Rev. 35 (1981); Veeder, Indian Water Rights and the Energy Crisis, in ENERGY RESOURCE DEVELOPMENT 184, 196 (1978) ("[I]t has been estimated that there are approximately 34 billion tons of coal underlying the Yellowstone River basin coalfields."). 
related purposes because this was the initial purpose of the reservation." $"$ 65

By concluding that the reservation's initial purpose in Arizona v. California was to create an agrarian society, the Special Master implied that once quantified, Indian water rights may extend to uses unforeseen at the time of the reservation's creation. This view would be consistent with the Court's rulings in Winters and Alaska Pacific, which found the reservation's purpose to include the arts of civilization and the advancement of civilized life. Nevertheless, while Indian water use has extended beyond crop irrigation, ${ }^{66}$ it has remained within the reservation's boundary.

\section{Ninth Circuit Court of Appeals Cases}

The Ninth Circuit Court of Appeals has been influential in defining the characteristics of a reservation's purpose, and hence has provided some guidance for ascertaining the permissible uses of an Indian water right. ${ }^{67}$ In Conrad Inc. v. United States, ${ }^{68}$ decided just two months after Winters, the Ninth Circuit ruled that the defendant could not obstruct the stream flow in a manner that affected the water rights of the Indians on the Blackfeet Indian reservation. Consistent with Winters, the Conrad court determined that the Blackfeet Indians had the parainount right to use the waters of Birch Creek "to the extent reasonably necessary for the purposes of irrigation and stock raismg, and doinestic and other useful purposes." 69 "Other useful purposes" echoes the "arts of civilization" and the "ways of civilization" language used by the Supreme Court in Winters and Alaska Pacific. Although the court did not say whether Indian water use can extend off the reservation, its language inplies a flexible approach to determining whether a particular Indian water use, unforeseen at the time of the reservation's creation, is permissible.

The flexibility implied by the Conrad court later was expressed in another Ninth Circuit opinion, United States v. Finch. ${ }^{70}$ Finch involved a defendant who had trespassed within the exterior boundaries of the Crow Indian reservation by fishing on the bank of the Big Horn River in Mon-

65. Report of Special Master Rifkind 265-66, Arizona v. California, 373 U.S. 546 (1963); see also Washington v. Fishing Vessel Ass'n, 443 U.S. 658, 686 (1979), where the Supreme Court placed a ceiling on the extent of Indian water rights: "Indian treaty rights to a natural resource that once was thoroughly and exclusively exploited by the Indians secures so much as, but not more than, is necessary to provide the Indians with a livelihood-that is to say, a moderate living."

66. See supra note 18 .

67. Due to the concentration of water law issues in the West, the Ninth Circuit has been the most significant forum for federal water law cases.

68. 161 F. 829 (9th Cir. 1908).

69. Id. at 831 .

70. S48 F.2d 822 (9th Cir. 1976), vacated on other grounds, 433 U.S. 676 (1977). 
tana. In addressing the issue of whether the Crow Indians could maintain a fishery, the court noted that the reservation was set aside as a "permanent home". ${ }^{71}$ The court went on to explain that:

The aim of the United States, . . was to fix the Crows in one location and to reorient their way of life toward 'agricultural and other pursuits.' We find it inconceivable that the United States intended to withhold from the Indians the right to sustain themselves from any source of food which might be available on their reservation. It must have been no mystery to the Government that the Crow Tribe, whose nomadic ways they sought to change, might eventually be forced to derive their existence from a source other than big game $\ldots .^{72}$

Finch held the fishery to be among the intended purposes of the Crow Indian reservation, even though the Crow were historically not a fishing people. ${ }^{73}$ Finch also supports the assertion that an Indian reservation was not created for the single purpose of producing an Indian agrarian society since "other pursuits"74 were exphicitly included as part of the tribe's effort in advancing toward civilized life.

Another Ninth Circuit case developing the characteristics of an Indian reservation is Moore $v$. United States. ${ }^{75}$ Moore concerned the issue of whether the river bed and tidal waters of the Pacific Ocean bordering a reservation were included within the reservation's boundaries. The Ninth Circuit found that when the Quillayute Indians relinquished to the United States all claims to the territory of Washington in the Treaty of 1855 , the Indians in turn received a tract of land "sufficient for their wants" and "set apart for their exclusive use."76 Citing the "industrial and commercial development" language in Alaska Pacific, ${ }^{77}$ the Court stated:

We know of no Indian tribe im which the native skills in hunting and fishing were more highly developed into the so-called 'American way of hife' $m$ mdustry and commerce, than in the Quillayutes .... The fact is that by 1889 the Quillayutes had a small whaling enterprise, a fur seal skin industry, ... and a salmon seining industry with a commerce in the raw and smoked fish. ${ }^{78}$

As in Alaska Pacific, the court reasoned that such activities promoted a key component of an Indian reservation, that of encouraging Indians to become industrious, self-supporting, and advancing in the ways of civi-

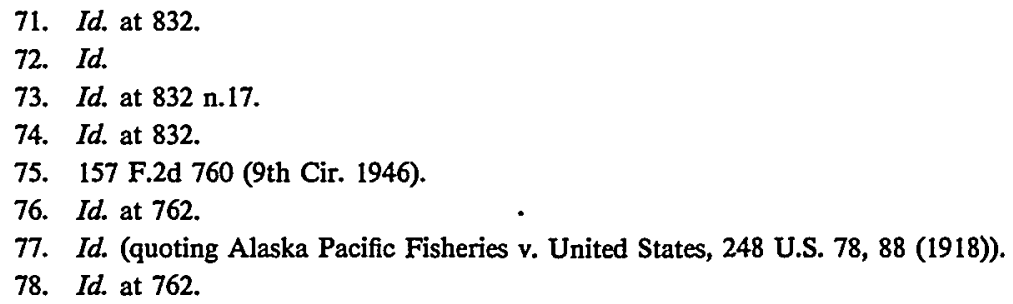


lized life. The court therefore concluded that the river bed and tidal waters were reserved for Indian use.

In the preceding cases, the courts looked first to the terms of individual treaties, agreements, or statutes creating the reservation to ascertain the reservation's purpose. Tlius, it may not be possible to attribute a common purpose to all Indian reservations because reservations were individually created for culturally different tribes who supported their livelihood by different ineans. Nonetheless, many treaties contain similar articles and covenants. ${ }^{79}$ In highlighting the characteristics of an Indian reservation as construed by the courts, this Comment suggests that focusing upon these similarities can help to proinote uniformity in determining the permissible scope of Indian water uses.

This Comment does not contend that individual treaties should be ignored by the court in favor of a general definition of a reservation's purpose. On the contrary, it respects the priority of specific provisions that provide clear directives regarding Indian water rights. ${ }^{80}$ Unfortunately, treaties rarely contain such specific language bearing on particular uses of Indian water rights. The United States government and

79. Treaties generally include a preamble on peace and friendship, and provisions regarding the geographic boundaries of the reservation, inaterial goods to be given by the United States, cash payment to the tribe, the intention that workmen, shops and schools be established on the reservation, and the binding effect of the treaty once ratified by Congress. See, e.g., Treaty with the Crows, 1868, arts. 3 \& 6, 2 LAws \& TREATIES 1008-09 (United States agrees at its expense to build "a warehouse or store-rooin . . . a residence for the physician . . . and five other buildings, for a carpenter, farmer, blacksinith, miller, and engineer." Further, the governunent shall supply "a good steam circular saw-nill, with a grist-mill and shingle-inachine attached"); Treaty with the Eastern Band Shoshoni and Bannock, 1868, arts. 3 \& 6, 2 LAwS \& TREATIES 1021-22 (United States agrees at its expense, to build " a warehouse or store-room . . . a residence for the physician . . . and five other buildings, for a carpenter, farmer, blacksmith, miller, and engineer," and to supply "a good steam circular saw-mill, with a grist-mill and shingle-machine attached"); Treaty with the Western Cherokee, 1833, art. 4, 2 Laws \& TREaties 397 ("United States will cause to be erected . . . four blacksmith shops, one wagon maker shop, one wheelwright shop, and necessary tools and implements furnished for the same; together with one ton of iron, and two hundred and fifty pounds of steel, [and] eight patent railway corn mills."); Treaty with the Creeks, 1833, art. 5, 2 LAws \& TREATIES 390-91 (United States to furnish "one blacksmith and one wheclwright or wagonmaker ... to erect shops and furnish tools for the same, and supply the smith shops with one ton of iron and two hundred and fifty pounds of steel each; [and] four patent railway mills, for grinding corn"); Treaty with the Chippewa, 1819, art. 8, 2 LAws \& TREATIES 186 (1904) ("The United States engage to provide and support a blacksunith for the Indians ... and to furnish the Chippewa Indians with such farming utensils and cattle, and to employ such persons to aid them in their agriculture ....").

80. As a case in point, the 1820 Treaty with the Chippewa Indian tribe provides that the "United States will secure to the Indians a perpetual right of fishing at the falls of St. Mary's." Treaty with the Chippewa, 1820, art. 3, 2 LAws \& Treaties 188 (1904). Should non-Chippewa development lower or contaminate the water supply, thereby endangering the fish population, the Chippewa could assert their treaty right to maintain the necessary quantity and quality of water to protect their fishing rights. Cf. Cappaert v. United States, 426 U.S. 128 (1976) (enjoining land owner from pumping water below levels necessary to maintain rare species of fish on federal reservation lands). As did the United States in Cappaert, the Chippewa could assert their reserved rights to protect the fish population. 
Indian tribes could not have anticipated the many issues currently raised concerning the scope and use of Indian water rights at the time the reservations were created. Even if these issues were foreseen, it is unlikely that the parties would have addressed every potential use of those rights in the treaty. Thus courts have had to consider the intent of the parties in establishing the reservation $\mathrm{m}$ order to determine whether particular water uses are permissible. ${ }^{81}$ Courts have considered the events surrounding the treaty, correspondence and negotiations between the Umited States and the particular tribe, tribal history, aboriginal uses of water, ${ }^{82}$. and Federal-Indian relations in general. ${ }^{83}$ Where there are ambiguities, courts have consistently ruled that doubtful terms must be construed in favor of the Indians. ${ }^{84}$ Even though tribes are culturally different, and the documents creating an Indian reservation are specifi-

81. For example, the Supreme Court has held that the Menominee Indian reservation was intended to be a place where the Menominees could "maintain ... their way of life which include[s] hunting and fishing." Menominee Tribe of Indians v. United States, 391 U.S. 404, 406 (1968). In addressing whether the Crow Indians could maintain a fishery, the Ninth Circuit stated that it was "inconceivable that the United States intended to withhold from the Indians the right to sustain themselves from any source of food which might be available on [the Crow Indian] reservation." United States v. Finch, 548 F.2d 822, 832 (9th Cir. 1976), vacated on other grounds, 433 U.S. 676 (1977). Ironically, Finch found the fishery to be among the intended purposes of the Crow Indian reservation in Montana, even though the Crow were historically not a fishing people. Also, in Alaska Pacific Fisheries v. United States, 248 U.S. 78 (1918), the Supreme Court found that the purpose of the Annette Island Reservation was "to encourage, assist and protect the Indians in their effort to train themselves to [adopt the] habits of industry, become self-sustaining, and advance to the ways of civilized life." Id. at 89 . At issue was whether the reservation included adjacent deep waters and whether a fish net constructed 600 feet beyond the high tide line by the Alaska Pacific Fisheries corporation was subject to abatement. Id. at 89. Applying the rule of construction presumptively favoring the Indians, the Court concluded that the Indians "are recognized as the only persons to whom permits [in the surrounding deep waters] may be issued for erecting salmon traps at these islands." Id. at 90.

82. "Aboriginal" is used here to mean those uses of water by the tribe prior to eontact with the Europeans. An example would be a tribe's historical dependence on fishing.

83. Finch, 548 F.2d at 830 .

84. See Alaska Pacific Fisheries, 248 U.S. at 89; Winters v. United States, 207 U.S. 564, 569 (1908); Finch, 548 F.2d at 830 . This rule of construction was articulated by Justice M'Lean in his concurring opinion in Worcester v. Georgia, 31 U.S. (6 Pet.) 515, 581 (1832) ("[T] he language used in treaties with the Indians should never be construed to their prejudice .... . How the words of the treaty were understood by this unlettered people, rather than their critical meaning, should form the rule of construction."); see also Carpenter v. Shaw, 280 U.S. 363, 367 (1930) ("Doubtful expressions are to be resolved in favor of the weak and defenseless people who are the wards of the nation, dependent upon its protection and good faith."). But see Shrago, supra note 14, at 1142-43 (arguing that the rationale supporting the rule, that Indians are too unlettered to understand treaty language, no longer applies and that accordingly the Supreme Court does little more today than pay lip service to it).

Professors Deloria and Lytle recently noted that the rules of construction were created by the courts (rather than by Congress) as an aid for settling Indian legal disputes. They further noted that among other things, the rules require that Indian treaties be interpreted as the Indians would have understood them at the time the treaty was made, and that treaties are to be interpreted as reserving to Indians all rights that have not been expressly relinquished. V. DELOR1A \& C. LYTLE, AMERICAN INDIANS, AMERICAN JUSTICE 48 (1983). 
cally reviewed, general guidelines are necessary to reduce uncertainties and promote uniformity in future court decisions involving the use of Indian water rights.

\section{The Wind River Case}

If a clear understanding of the purpose of an Indian reservation is lacking, courts can err in defining the permissible extent of Indian water uses. In Arizona v. California, the United States Supreine Court defined the inethod for quantifying the extent of Indian water rights, ${ }^{85}$ but the Court has yet to decide the extent of Indian water uses once the right is quantified. Without a proper understanding of a reservation's purpose, courts can confuse Supreine Court directives on the permissible extent of the right with the permissible extent of Indian water uses.

A prime exainple of mistakes in interpreting the purpose of a reservation is In Re the General Adjudication of All Rights to Use Water in the Big Horn River System and Other Sources, State of Wyoming (hereinafter Wind River). ${ }^{86}$ On appeal in Wind River, the Wyoning Supreme Court reviewed the trial court's determination of the purpose of the Wind River Indian Reservation. The trial court's analysis had differed substantially froin that of the court-appointed Special Master. Both the trial court and Special Master failed to distinguish between the method of quantifying Indian water rights with federal court directives on determining the extent of permissible Indian water uses. The Wyoming Supreme Court majority also failed to carefully consider this distinction and affirmed the trial court's conclusions on the reservation's purpose. ${ }^{87}$

In construing the reservation's purpose, the Special Master looked first to the language of the treaty creating the reservation. He noted that article four of the treaty stated that the Indians "will make said reservations their permanent home" and that article six noted that they may "desire to commence farming." "the principal purpose of the United States in entering into the Treaty of 1868 was to provide a permanent homeland for the Indians so that they may, in whatever way most suitable to their development, establish a permanent civilization on the Wind River Indian Reservation."89 This construction follows the United States Supreme Court's language in Winters and Alaska Pacific. In Winters, the Supreme Court implied that the "arts of civilization" were among the intended purposes of the Indian

85. 373 U.S. 546 (1963).

86. Wind River, supra note 26, 753 P.2d 76 (1988).

87. Id. at 96.

88. Id. at 95 .

89. Report of the Special Master 67, In re General Adjudication of All Rights to Use Water in the Big Horn River System and All Other Sources, Civ. No. 4993 (Wyo. Dist. Ct. May 10, 1982), [hereinafter Report of the Special Master, Wind River]. 
reservation, ${ }^{90}$ and in Alaska Pacific, that the purposes included industrial and commercial development. ${ }^{91}$ Further, the Special Master's conclusion was similar to that in United States $v$. Finch, ${ }^{92}$ where the Ninth Circuit construed a "permanent homeland" to include the use of a fishery as one of the reservation's intended purposes, even though the Crow Indians were not a fishing people by tradition..$^{93}$ Consistent with these cases, the Special Master did not limit the use of the quantified Indian water right to agricultural pursuits. ${ }^{94}$ Yet, the Special Master went beyond the Uinited States Supreme Court's method of quantifying Indian water rights established in Arizona $v$. California, ${ }^{95}$ and awarded additional water for uses otlier than agriculture, stock water, and domestic use. ${ }^{96}$

The Wind River trial court rejected the Special Master's findings and reached the opposite conclusion. In construing the purpose of the Wind River Indian Reservation, the trial court concluded that Congress did not intend to provide a permanent home, but simply required the tribe to live on the reservation rather than elsewliere. The court defined the purpose of the reservation as "purely agricultural," and stated that "Congress had no other purpose beyond that of converting the Indians froin a nomadic to an agrarian people."97 The Wyoining Supreme Court agreed. While also looking to the specific language of the treaty, the Wyoming Supreine Court majority concluded that Congress intended the "primary activity" to be "clearly agricultural."98 Although both courts

90. Winters v. United States, 207 U.S. 564, 576 (1908).

91. Alaska Pacific Fisheries v. United States, 248 U.S. 78, 89 (1918).

92. 548 F.2d 822 (9th Cir. 1976), vacated on other grounds, 433 U.S. 676 (1977).

93. See supra notes 71-74 and accompanying text.

94. The Special Master would have allowed water uses for fish and wildlife preservation mineral, municipal, and industrial development, and aesthetic purposes, in addition to agricultural uses and stock water. Wind River, supra note 26,753 P.2d at 85. Referring to Winters, the Special Master stated that "[a]ny other conclusion [regarding any other purpose] would appear to be contrived, and contrary to Supreme Court precedent." Report of the Special Master, Wind River, supra note 89 , at 60 .

95. 373 U.S. 546 (1963) (describing the "practicably irrigable acreage" test); see supra note 64.

96. See supra note 94 . This is not to suggest a treaty may never require water to be quantified for purposes beyond agricultural and related uses. See discussion supra text following note 80 .

97. Wind River, supra note 26, 753 P.2d at 95. See also In re General Adjudication of All Rights to Use Water in the Big Horn River System and All Other Sources, Civ. No. 4993 (Wyo. Dist. Ct. May 10, 1983), at 16 [hereinafter Trial Court Opinion, Wind River].

98. Id. at 98. (" 'Permanent homeland' does nothing more than permanently set aside lands for the Indians; it does not define the purpose of the reservation.") Id. at 97. The various interpretations of the reservation's purpose as demonstrated by the Wyoming Supreme Court serves to underscore the need for uniform guidelines to determine the extent of permissible Indian water uses. Dissenting on the issue of the reservation's purpose was Justice Thomas with whom Hanscum, District Judge, joined. Justice Thomas correctly construed congressional intent by stating that the majority's analysis "assumes that the Indian peoples will not enjoy the same style of evolution as other people, not are they to have the benefits of modern civilization." 753 P.2d at 119 (Thomas, J. dissenting). Justice Thomas aptly understood that the "[I]ndian homeland ... will not be a static place frozen in an instant of time but that the homeland will evolve and will be used in different ways as the Indian 
erroneously construed congressional intent, ${ }^{99}$ the Wyoming Supreme Court quantified the Indian water right consistent with Arizona v. California, ${ }^{100}$ and awarded the amount of water needed for agricultural, do1nestic, and hivestock purposes only. ${ }^{101}$

Once the reserved right was quantified, however, the trial court went on to limit the particular uses of the Indian water right. For example, the trial court expressly denied any off-reservation water use. ${ }^{102}$ The Wyoming Suprenie Court should have considered the trial court's analysis because the trial court's restriction on the use of the Indian water right was erroneous for two reasons. First, the trial court expressed concern that mjury would result to non-Indian water users if the Indians exercised their water rights. The trial court feared a "gallon-for-gallon" reduction in non-Indian water uses, and thus it felt "compelled to apply a more strict interpretation of the reserved right theory." 103 In doing so,

society develops." Id. Nonetheless, Justice Thomas would have limited the use of the Indian water right to on-reservation purposes.

District Judge Hanscum filed a separate dissent concurring with Justice Thomas' analysis of the reservation's purpose. Judge Hanscum went one step further, and stated that the "sale of water off the reservation should be permitted, provided that, as a factual matter, it could be demonstrated that such marketing contributed to the progress and development of the Indian homeland." 753 P.2d at 135 (Hanscum, District Judge, dissenting). Judge Hanscum reasoned that "to preclude the opportunity of proving such a nexus unduly would restrict and hamper the prospective development of the Indian homeland in the future." Id.

99. See infra Part II (discussing congressional intent for creating and maintaining Indian reservations).

100. 373 U.S. 546 (1963).

101. Wind River, supra note 26, 753 P.2d at $98-99$.

102. Id. at 99. The Wyoming Supreme Court declined to address this issue.

103. The trial court's conclusion is indicative of tribal concerns that the quantification of Indian water rights is a substantial risk in state courts. See supra note 16 and accompanying text. Concerned about state court biases against Indian reserved rights in the arid West, Senator Edward Kennedy has called for fair and consistent water adjudications: "Indian water rights-no matter how critieal to a tribe's future, no matter how well inventoried, no matter how brilliantly defended by government attorneys, cannot receive full protection in state court forums." Indian Water Rights: Hearings Before the Subcomm. on Administrative Practice and Procedure of the Senate Comm. on the Judiciary, 94th Cong., 2nd Sess. 2 (1976).

The desire to free Indian rights from state court jurisdiction "stems from the long-standing power struggle between tribes and states-the states' jealousy of Indian tribal sovereignty and the often vehement opposition of tribes to state jurisdiction over their persons and property." Note, supra note 15, at 230. The Supreme Court first observed the states' opposition to tribal rights in Worcester v. Georgia, 31 U.S. (6 Pet.) 515 (1832) and later noted that the "people of the States where [lndians] are found are often their deadliest enemies." United States v. Kagama, 118 U.S. 375, 384 (1886). Likewise, in his dissent in Arizona v. San Carlos Apache Tribe, 463 U.S. 545 (1983), Justice Stevens noted that "States and their citizens may well be more antagonistic toward Indian reserved rights than other federal reserved rights [such as national parks], both because the former are potentially greater in quantity and because they provide few direct or indirect benefits to non-Indian residents." Id. at 575 (Stevens, J., dissenting).

The open hostility of many westerners to the reserved rights doctrine heightens Indian fear of state court adjudications. This antagonism is reflected in an amicus curiae brief submitted on behalf of the state of Wyoming in United States v. District Court, 401 U.S. 520 (1971), which urged the Court to abrogate the reserved rights doctrine because it operates in derogation of very large 
the court went beyond United States Supreme Court precedent, which has specifically rejected such potential injury claims when determining the scope of Indian water rights. ${ }^{104}$

Second, because the federal courts have provided few express directives on which characteristics are essential in defining a reservation's purpose, the trial court had little guidance in interpreting the intent of Congress in establishing a "permanent homeland"105 for the Indians. The court mistakenly concluded that Congress had no other purpose beyond that of converting the Indians from a nomadic to an agrarian people, and therefore limited Indian water uses to on-reservation agricultural pursuits. Although the United States Supreme Court has quantified only the amount of Indian water rights based on "practicably irrigable acreage," 106 the case law in no way limits the use of the quantified right to agricultural pursuits. ${ }^{107}$ Indeed, if Indian water uses were limited to growing crops, then current on-reservation water uses for mining and industrial operations, recreation, and education would be invalid. ${ }^{108}$ Thus, without proper guidelines for understanding congressional intent in creating and inaintaining an Indian reservation, courts can, and have, erred in determining the permissible scope of Indian water uses.

established [non-Indianl economic interests. Brief for the State of Wyoming at 20, 21, 40-41, id. (No. 87) (cited in Note, supra note 64, at 1053 n.238).

104. See Winters v. United States, 207 U.S. 564, 570 (1908). The Winters Court found the Indian water rights paramount to state water appropriations. Commenting on Winters, the Ninth Circuit noted that "the Indians were awarded the paramount right regardless of the quantity remaining for the use of white settlers." United States v. Ahtanum Irrigation Dist., 236 F.2d 321, 327 (9th Cir. 1956). The Ninth Circuit went on to say:

What the non-Indian appropriators may have is only the excess over and above the amounts reserved for the Indians. It is plain that if the amount awarded the United States for the benefit of the Indians in the Winters case equaled the entire flow of the Milk River, the decree would have been no different.

Id.

105. Wind River, supra note 26, 753 P.2d 94.

106. Arizona v. California, 373 U.S. 546 (1963) (describing the "practicably irrigable acreage" test); see supra note 64 .

107. See infra cases discussed in Part II. The Solicitor from the Department of the Interior responded to the Special Masters' decree in a letter to the Secretary of the Interior regarding Indian water rights in a nonagricultural lease. The Solicitor stated that "there is no reason for concluding that the Indians' water rights must be used only for agricultural purposes any more than for concluding that the lands must be used for agriculture." Letter from the Office of the Solicitor to the Secretary of the 1nterior, Water Rights in Case of Non-Agricultural Lease-Colorado River Reservation (Feb. 1, 1964) (copy on file with author). The Solicitor further emphasized that, "Indian lands and water may bring larger returns or other benefits to their owners if used for commercial or industrial purposes than if cultivated for crops." Id. In other words, preeluding changes in the type of water use would "inhibit sound and practical land and water use decisions" as well as prohibit Indian reservations from functioning as "self-sufficient economic units." Id. The Supreme Court has not yet ruled on the propriety of an off-reservation transfer of water use. See infra text accompanying notes 181-84.

108. See supra note 18 and accompanying text; infra note 222 and accompanying text. 
II

\section{CONGRESSIONAL INTENT AND APPROPRIATE GUIDELINES}

Part I of this Comment evaluated the characteristics and common purpose of an Indian reservation as presented by the courts. It demonstrated how the lack of clear directives regarding the purpose of an Indian reservation can produce erroneous determinations on the scope of Indian water uses. To address this problem, Part II exammes the intent of the Indians and Congress in establishing a reservation, and provides guidelines for determining whether a particular Indian water use is consistent with that reservation's purpose. The following historical review of the relations between the United States government and Indian tribes reveals that a consistent purpose of the government was to civilize the Indians: making them productive, tribally independent, ${ }^{109}$ American citizens. ${ }^{110}$ Throughout the late nineteenth and twentieth centuries, Congress has attempted to implement programs aimed at encouraging Indians to be industrious, and thereby achieve the same economic and social opportunities enjoyed by other Americans. ${ }^{11}$ Off-reservation

109. This reference concerns the issue of tribal sovereignty, an extensive topic beyond the scope of this Comment. The relevance of tribal sovereignty with respect to water rights is most relevant in water management, jurisdictional, and conservation issues. Excellent resources on the subject include V. Deloria \& C. Lytle, The Nations Within: The Past and Future of American INDIAN SOVEREIGNTY (1984); G. GROSSMAN, THE SOVEREIGNTY OF AMERICAN INDIAN TRIBES: A MATTER OF LEGal History (1979); K. KICKINGBIRD, INDIAN SOVEREIGNTY (1977); Deloria, The Era of Indian Self-Determination: An Overview, in INDIAN SELF-Rule 191, 207 (K. Philip ed. 1985); Wilkinson, Indian Control and Use of Water for Mineral Development, in INDIAN LAND Development: OIL, Gas, COAL AND OTher Minerals (Rocky Mountain Mineral Law Foundation ed. 1976).

110. See F. Cohen, Handbook of Federal Indian Law 23 (1945);

The Indians must conform to 'the white man's ways,' peaceably if they will, forcibly if they must. They must adjust themselves to their environment, and conform their mode of living substantially to our civilization .... They can not escape [this American civilization], and must either conform to it or be crushed by it.

(quoting Commissioner Thomas J. Morgan of the Republican Committee on Indian Affairs, 1889); see also House Comm. on Indian Affairs, House Committee Report, Jan. 22, 1818, 2 AMERICAN STATE Papers: INDIAN AFFaIRS, 15th Cong., 1st. Sess. 151 (1834):

Put into the hands of their children the primer and the hoe, and they will naturally, in time, take hold of the plough; and, as their minds become enlightened and expand, the Bible will be their Book, and they will grow up in habits of morality and industry ... and become useful members of society.

111. See, e.g., Indian General Allotment Act (Dawes Act), ch. 119, § 1, 24 Stat. 388 (1887) (codified as amended at 25 U.S.C. $\$ \S 331-338$ (1982)) (providing allotments of reservation land in severalty to Indians for agricultural or grazing purposes); Indian Self-Determination Act, Pub. L. No. 93-638, $§ 2,88$ Stat. 2203 (1975) (codified as amended at 25 U.S.C. $\S 450$ (1982)) (assuring maximum Indian participation in direction of educational and other federal services to Indian communities); Indian Reorganization Act (Wheeler-Howard Act), ch. 576, 48 Stat. 984 (1934) (codified as amended at 25 U.S.C. $\$ \$ 461-479$ (1982)) (terminating allotment of reservation lands in severalty and restoring lands to tribal ownership); Indian Civil Rights Act of 1968, Pub. L. No. 90 284, tit. II, $\S 201,82$ Stat. 77 (1968) (codified as amended at 25 U.S.C. $\S \S 1301-1303$ (1982)) (recognizing tribal powers of self-government, and jurisdiction of Indian courts under laws of federal constitution); Indian Financing Act of 1974, Pub. L. No. 93-262, $\S 2,88$ Stat 77 (1974) (codified as 
leases of Indian water rights further such congressional policies and thus are a use consistent with the purposes of the reservation.

\section{A. The History of Federal-Indian Relations}

\section{The Early Years}

According to the Bureau of Indian Affairs, Indians during the colonial period represented a "strong balance of power between the forces of Spain, France, and England and were therefore treated as sovereign nations." 112 After the American government won its independence from Britain, it continued to negotiate with the Indians as sovereign nations. In 1775, the Continental Congress established Indian Commissioners who, given authority "to treat with the Indians," made 370 Indian treaties over the next century. ${ }^{113}$

The Northwest Ordmance Act of $1789^{114}$ reiterated the idea that tribes were to be respected as sovereign nations. The Act expressed the government's purported policy toward tribal reservation lands, stating that "[t]he utnost good faith shall always be observed toward the Indians; their land and property shall never be taken from them without their consent; and in their property, rights and liberty, they shall never be invaded or disturbed." 115

In 1830, however, the Indian Removal Act ${ }^{116}$ was enacted and for the next fifty-seven years Indians were forcibly taken from their homelands and inoved to the desert land reservations of the West. Although the government's removal policy was designed to free lands east of the Mississippi River for the encroaching European population, ${ }^{117}$ the gov-

amended at 25 U.S.C. $\$ \$ 1451-1453$ (1982)) (congressional policy to provide capital on reimbursable basis to help develop Indian resources, from their own productive efforts, to a standard of living enjoyed by non-Indians in neighboring communities); Native American Programs Act of 1974, Pub. L. No. 88-452, tit. VIII, $\S 801,88$ Stat. 2324, (1975) (codified as amended at 42 U.S.C. $\$ \S 2991-2992$ (1982)) (providing financial assistance for tribal programs previously conducted without federal assistance).

112. U.S. Dep't of the Interior, Federal Indian Policies . . . From the Colonial Period Through the EarLy 1970's 3 (1975) [hereinafter Federal INDIAN Policies]; see also W. WASHBuRn, Red MAN's LAND, White MAN's LAW 47-50, 54 (1971); F. Cohen, supra note 110 , at 28 :

During the years when the rivalries of England, France and Spain on the continent gave the various Indian tribes positions of strategic power, negotiations with these tribes were carried on by the Colonies and later by the United States on the basis of international treaties. These treaties acknowledge the sovereignty of Indian tribes and implied the acknowledgement of a possessory right in the soil that the tribes occupied.

(quoting The Office of Indian Affairs).

113. Federal Indian Policies, supra note 112, at 3-4.

114. Northwest Ordinance Act of 1789, 1 Stat. 50.

115. Id.

116. The Indian Removal Act of $1830, \mathrm{ch} .148, \S \S 7-8,4$ Stat. 412 (codified as amended at 25 U.S.C. $\S 174$ (1982)).

117. See F. Cohen, supra note 110 , at 53; see also R. SATz, AMERICAN INDIAN PolicY IN THE 
ernment also wanted Indians to assimilate by adopting American values and practices. Native religions were discouraged and many Indian ceremonies were forbidden during this period. ${ }^{118}$ Christian missionaries and vocational schools were established on reservations for the purpose of encouraging Indians to adopt "civilized" traits. ${ }^{119}$ Activities such as livestock grazing and irrigation were especially encouraged because "Indian lands lagged behind the national efforts [in land resource development] as a whole." 120 This ethnocentrism is reffected in a statement made by one Indian Commissioner at the time:

Can any principle of national morality be dearer than that when the expansion and development of a civilized race involve the rapid destruction of the only means of subsistence possessed by members of a less fortunate race, the higher is bound as a simple right to provide for the lower some substitute for the means of subsistence which it has destroyed? That substitute is, of course, best realized, not by systematic gratuities of food and clothing contimued beyond a present emergency, but by directing these people to new pursuits which shall be consistent with the progress of civilization upon the continent. ${ }^{121}$

Throughout this period of Federal-Indian relations, the Indian tribes were treated as sovereign nations possessing property, riglits, and hiberty. ${ }^{122}$ As sovereign nations, tribes were encouraged to change from their old ways and to adopt American practices. The government promoted pastoral activities to develop reservation lands and encourage American industriousness. ${ }^{123}$ Yet no activity was expressly deried. In fact, the intent of the government was to furtlier tribal self-sufficiency by pursuits that were "consistent with the progress of civilization upon the continent." 124 Thus, the government intended that Indians have the

JACKSON1AN ERA 1-2 (1975) (assimilating the Indians into American society justified the federal Indian policy that required tribes to relinquish their land as the non-Indians demanded it); U.S. COMM'N ON CIVIL RIghts, INDIAN TRIBES: A CONTINUING QUEST FOR SURVIVAL 18-19 (1981) [hereinafter INDIAN TRIBES] ("Thomas Jefferson proposed a constitutional amendment to exchange the Indian land east of the Mississippi for land west of that boundary. This amendment failed, but subsequently congressional authorization was obtained on the same question.").

118. Federal Indian Policies, supra note 112, at 6; see also F. CohEN, supra note 110, at 28 (citing Office of Indian Affairs, 1938) ("The guiding concepts . . . were the destruction of all Indian tribal bonds, the effacing of Indian languages and cultural heritages, the forcing of the Indian as an individual to become identified with and lost in the white hife ....").

119. FEDERAI INDIAN Policies, supra note 112, at 6 . The government's desire that the Indians receive conventional education was often manifested in treaty provisions. For example, the Eastern Band Shoshoni and Bannock "pledge[d] themselves to compel their children, male and feinale, between the ages of six and sixteen years, to attend school ..." Treaty with the Eastern Band Shoshoni and Bannock, 1868, art. 7, 2 LAws \& Treaties 1020, 1022 (1904).

120. FEDERAL INDIAN POLICIES, supra note 112 , at 7 .

121. Id. at 6 (Statement of Commissioner Francis Walker) (emphasis added).

122. Id. at $3-4$.

123. Id. at 7 .

124. Id. 
opportunity to pursue the economic activities enjoyed by American citizens. As shown below, the government thought that this goal would be advanced by promoting the American value of individualism through ownership of private property.

\section{The Development of Individual Ownership: 1887-1934}

A systematic effort to encourage American property values among the Indians began when the General Allotment Act was passed in 1887. ${ }^{125}$ The Act was intended to assimilate the Indians by granting individual plots of land to each family or male adult. It was thought that individual ownership of land, as opposed to the collective land use and possession practiced by most Indian groups, would encourage Indians to value mdividualism and to become farmers of private property like other Americans. ${ }^{126}$

The allotment system was also purported to facilitate the expansion of western civilization into Indian land in less paternal ways. Although the "civilizmg policy was in the long run to benefit Indian and white man alike," 127 the minority report of the House Indian Affairs Committee in 1880 stated that " $[\mathrm{t}]$ he real aim of this bill is to get at the Indian lands and open them up to settlement. The provisions for the apparent benefit of the Indian are but the pretext to get at his lands and occupy them."128 One result of the allotment policy was the reduction of Indian land holdings from over 140 million acres in 1886 to under 50 million acres by 1934. ${ }^{129}$

It was during this period that the Fort Belknap reservation in Winters was established. On its face, the treaty provided many opportumities for the Indians because the United States assured the tribes that funds and services would be made available "to educate their children in the paths of civilization .... and in any other respect to promote their civihzation, comfort, and improvement."130 In reality, these tribal

125. Indian General Allotment Act, ch. $119, \S 1,24$ Stat. 388 (1887) (codified as amended at 25 U.S.C. $\$ \S 331-358(1982))$.

126. Under this plan, 160 acres were granted to each family head, 80 acres to each single person over 18 years of age, and 40 acres to each other single person under 18. A patent in fee was to be issued to each allottee, but it was held in trust by the Government for 25 years, during which time the land could not be alienated. Moreover, citizenship was awarded to allottees (or any other Indians) who abandoned their tribes and adopted the habits of civilized life. "The supreme aim of the friends of the Indian was to substitute white civilization for his tribal culture, and they shrewdly sensed that the difference in the concepts of property was fundamental in the contrast between the two ways of life." F. CoHEN, supra note 110, at 207-08.

127. Id.

128. H.R. REPS. No. 1576, 46th Cong., 2d Sess. 10 (1880).

129. Federal INDian Policies, supra note 112, at 7.

130. Agreement with the Indians of the Fort Belknap Indian Reservation in Montana, art. 2, 1 LAws \& TREATIEs 601, 602 (1904) [hereinafter Fort Belknap Treatyl. 
opportunities were limited because the United States failed to provide adequate funds and supplies, and delivered them primarily "to those who in good faith under[took] the cultivation of the soil, or engag[ed] in pastoral pursuits." 131 The Fort Belknap treaty also described the Indians as being "desirous" of becoming a "pastoral and agricultural people."132 Thus, in operation, the language of this treaty and similar language contained in other treaties made with other Indian tribes, typically encouraged farming among the Indians during the period of the Government's allotment policy. ${ }^{133}$

\section{Post-1934 Attempts to Foster "Civilization": Indian Reorganization and Self-Determination}

In response to the 1928 Meriam Report ${ }^{134}$ attacking the failure of the allotment system to assist the Indians in pursuing a pastoral life, Congress enacted the Indian Reorganization Act of 1934. ${ }^{135}$ The Act "brought a halt to the process of allotment, prohibited unrestricted sales of Indian land, and provided for acquisition of additional lands by tribes and individuals." ${ }^{36}$ The Indian Reorganization Act apparently was a congressional recognition of tribal law, tribal organization, and general tribal self-government. ${ }^{137}$ This Act restated an earlier pohicy that recognized Indian tribes as sovereign nations and treated them accordingly. ${ }^{138}$ Yet Congress also intended that Indians continue to adopt American values. As a result, the Indian Reorganization Act inaugurated the so-

131. Hundley, supra note 9, at 21 (quoting Fort Belknap Treaty, supra note 130, art. 4).

132. Fort Belknap Treaty, supra note 130 , art. 3.

133. See supra note 79.

134. In 1928, Lewis Meriam, in conjunction with the Institute of Government Research (the "Brookings Institution"), published a lengthy document, The Problem of Indian Administration, commonly known as the Meriam Report, attacking the allotment system:

When the Government adopted the policy of individual ownership of land on the reservations, the expectation was that the Indians would become farmers. Part of the plan was to instruct and aid them in agriculture, but this vital part was not pressed with vigor and intelligence. It almost seems as if the Government assumed that some magic in individual ownership of property would in itself prove an educational civilizing factor, but unfortunately this policy has for the most part operated in the opposite direction.

Institute of Government Research, The Problem of Indian AdMINISTRation 7 (1928) (quoted in FEDERAL INDIAN Policies, supra note 112, at 8).

135. Indian Reorganization Act (Wheeler-Howard Act), ch. 576, 48 Stat. 984 (1934) (codified as amended at 25 U.S.C. $\$ \S 461-479$ (1982)). The Act endeavored to give Indian economic assistance "in the process of liberating and rejuvenating a subjugated and exploited race living in the midst of an aggressive civilization far ahead, materially speaking, of its own." FEDERAL INDIAN Policies, supra note 112, at 8.

136. FEDERAL INDIAN Policies, supra note 112, at 8.

137. See id. at 8-9; see also L. BuRT, TribalisM in CRISIS: FEDERAL INDIAN Policy, 19531961, 3 (1982); C. JACKSON \& M. GALLI, A HISTORY OF THE BUREAU OF INDIAN AFFAIRS AND ITS ACTIVITIES AMONG INDIANS 99-104 (1977).

138. See Northwest Ordinance Act of 1789,1 Stat. 50; see also supra text accompanying notes 114-15. 
called "termination" era during which Congress passed a series of bills terminating the government's trusteeship over Indian lands and property. ${ }^{139}$ The stated policy of Congress was to make Indians "subject to the same laws and entitled to the same privileges" that applied to other American citizens. ${ }^{140}$ Nevertheless, like other previous congressional efforts, this attempt to "civilize" the Indians had dire consequences for several Indian tribes. ${ }^{141}$

Recognizing that the termination era had not produced the intended results, Congress revived the concept of tribal self-government by passing the Self-Determination Act of $1970 .{ }^{142}$ Self-determination for Indian

139. See, e.g., Act of June 17, 1954, ch. 303, 68 Stat. 250, repealed by, Act of Dec. 22, 1973, Pub. L. No. 93-197, § 3(b), 87 Stat. 770 (Menominee); Act of Aug. 13, 1954, ch. 732, 68 Stat. 718, repealed by, Act of Aug. 14, 1957, Pub. L. No. 85-132, § 1(f), 71 Stat. 348 (Klamath); Act of Aug. 23,1954, ch. 831,68 Stat. 768 (codified as amended at 25 U.S.C. $\$ \S 721-728$ (1982)) (Alabama and Coushatta); Act of Aug. 27, 1954, ch. 1009, 68 Stat 868 (codified as amended at 25 U.S.C. $\$ 677$ (1982)) (Ute Tribe of Uintah and Ouray); Act of Sept. 1, 1954, ch. 1207, 68 Stat. 1099, repealed by, Act of Apr. 3, 1980, Pub. L. No. 96-227, § 2, 94 Stat. 317 (Paiute); Act of Aug. 1, 1956, ch. 843, 70 Stat. 895, repealed by, Act of May 15, 1978, Pub. L. No. 95-281, § 1(b)(1), 92 Stat. 246 (Wyandotte); Act of Aug. 2, 1956, ch. 881, 70 Stat. 937, repealed by, Act of May 15, 1978, Pub. L. No. 95-281, $\S 1$ (b)(2), 92 Stat. 246 (Peoria); Act of Aug. 3, 1956, ch. 909, 70 Stat. 963, repealed by, Act of May 15, 1978, Pub. L. No. 95-281, §1(b)(2), 92 Stat. 246 (Ottawa). For a thorough discussion of the government's trust relation to Indian tribes, see generally G. HALL, DUTY OF Protection: ThE FEDERAL-INDian TRUST RELATIONSHIP (1979).

140. H.R. Res. 108, 83rd Cong., 1st Sess. (1953).

141. The shift in policy toward the termination of federal responsibility and assimilation of reservation Indians abolished several reservations during the 1950's. "Termination" means that an Indian treaty will no longer be recognized by the United States and that the tribe no longer retains special rights as a sovereign nation. When a tribe is terminated, tribal property and assets held in trust by the United States for the benefit of the Indians arc transferred to the Indians, and jurisdiction over individual Indians, their property and their lands is transferred from the federal government to the states. After termination, tribal legal systems are no longer recognized, and individual Indians can no longer receive benefits and services such as Indian health care elinics from the United States. U.S. DEP'T OF THE INTERIOR, FEDERAL INDIAN LAW 134-35 (1958).

In the case of the Menominee Indians, the results of termination were especially severe. The Menominees had begun a successful timber operation on the reservation and were thought to be ready for termination because of this profitable enterprise. When the tribe was terminated from trust status, however, the state and local governments were permitted to tax the operation, public works, sewage, and other activities resulting in a financial crisis for the tribe. Because of the extreme hardships in conducting the timber business, Congress later repealed the termination. Act of June 17, 1954, ch. 303, 68 Stat. 250, repealed by, Act of Dec. 22, 1973, Pub. L. No. 93-197, § 3(b), 87 Stat. 770.

For another case in point, see W. Brophy \& S. ABERLE, The INDiAN: AMERICA's UNFINISHED BUSINESS (1966), where the authors examine the effects of termination on the Paiute Indians:

Registering to vote, complying with state regulations for hunting and fishing licenses, or obtaining farmers' home or other loans-such important aetivities were all beyond the experience and understanding of the Paiutes. Without birth certificates, Social Security numbers, land deeds, and a command of English and general know-how, they are relatively helpless. This one case amply demonstrates that the policy statement of Congress to make Indians ... subject to the same laws and entitled to the same privileges as are applicable to citizens of the United States' . . . is not accomplished by termination legislation.

Id. at 196.

142. Indian Self-Determination Act, Pub. L. No. 93-638, § 2, 88 Stat. 2203 (1975) (codified as 
people had been encouraged by President Nixon and others since the early 1960s. Prior to passage of the Act, President Nixon had called for various congressional actions which, among other things, ended the termination policy, shifted control of Indian programs, schools, and school boards to the tribes, and promoted Indian economic growth through natural resource exploitation on reservation lands. ${ }^{143}$ Within the framework of tribal self-government, Congress has subsequently encouraged economic development and American values through various programs. ${ }^{144}$

The foregoing discussion demonstrates how federal policy has consistently tried to encourage Indians to adopt and conform to mainstream America's culture. Although this policy has undergone various incarnations over the years, the policy has remamed virtually unchanged. In the early colonial years, federal Indian pohicy encouraged values based upon individual property ownership through the allotment process. Later, consistent with American industrial growth and economic opportunities, Congress encouraged the development of natural resources located on reservation lands. ${ }^{145}$ Self-determination is seen as consistent with these goals. As sovereign nations, tribes are encouraged to develop their culture, with the help of federal monies, toward economic self-sufficiency and other "markings" of civilized life.

amended at 25 U.S.C. $\S 450$ (1982)). The stated congressional purposes in enacting the Act were, inter alia:

To promote maximum Indian participation in the government and education of the Indian people; to provide for the full participation of Indian tribes in programs and services conducted by the Federal Government for Indians and to encourage the development of the human resources of the Indian people; to establish a program of assistance to upgrade Indian education; to support the right of Indian citizens to control their own educational activities; to train professionals in Indian education; [and] to establish an Indian youth intern program ....

H.R. REp. No. 93-1600, 93rd. Cong., 2nd Sess. 1, reprinted in 1974 U.S. Code Cong. \& AdmiN. NEws 7775, 7775-76.

143. See Federal Indian Policies, supra note 112, at 12.

144. Indian Self-Determination Act, Pub. L. No. 93-638, §2, 88 Stat. 2203 (1975) (codified as amended at 25 U.S.C. $\$ 450$ (1982)) (assuring maximum Indian participation in direction of educational and other federal services to Indian communities); Indian Reorganization Act (WheelerHoward Act), ch. 576, 48 Stat. 984 (1934) (codified as amended at 25 U.S.C. $\$ \S 461-479$ (1982)) (terminating allotment of reservation lands in severalty and restoring lands to tribal ownership); Indian Civil Rights Act of 1968, Pub. L. No. 90-284, tit. II, $\S 201,82$ Stat. 77 (1968) (codified as amended at 25 U.S.C. $\$ \S 1301-1303$ (1982)) (recognizing tribal powers of self-government, and jurisdiction of Indian courts under laws of federal constitution); Indian Financing Act of 1974, Pub. L. No. 93-262, § 2, 88 Stat 77 (1974) (codified as amended at 25 U.S.C. $\S \S 1451-1453$ (1982)) (congressional policy to provide capital on reimbursable basis to help develop Indian resources, from their own productive efforts, to a standard of living enjoyed by non-Indians in neighboring communities); Native American Programs Act of 1974, Pub. L. No. 88-452, tit. VIII, § 801, 88 Stat. 2324, (1975) (codified as amended at 42 U.S.C. $\$ \S 2991-2992$ (1982)) (providing financial assistance for tribal programs previously eonducted without federal assistance).

145. See, e.g., Indian Self-Determination Act, Pub. L. No. 93-638, § 2, 88 Stat. 2203 (1975) (codified as amended at 25 U.S.C. $\S 450$ (1982)). 


\section{B. Policy Guidelines for Determining the Permissibility of Indian Water Uses}

Given the government's overall policy toward Indian tribes noted in Part II, the following guidelines suggest themselves to assist courts in determining whether a particular use of Indian water rights is consistent with the purpose of the reservation. These guidelines derive from Congress' purpose in creating and maintaining reservations, and hence are subject to modification. Moreover, these guidelines are not comprehensive. Rather, they identify principles consistent with the two main themes of federal Indian policy: tribal self-government and the American way of life.

A. Indian tribes are to be treated as independent sovereign nations, enjoying the freedom to pursue activities that promote the economic selfsufficiency and welfare of the tribe. Any reasonable and beneficial water use that will promote these goals shall not be denied.

B. Indian water uses shall not be limited by the sum of the nations' progress at the time of the reservation's creation. Indians may pursue, and use water for, activities that promote a civilized life and that are enjoyed equally by American citizens throughout the years.

In determining whether a particular water use is consistent with the purpose of an Indian reservation, courts look to the individual treaty for specific directives, and then to the history surrounding the creation of the reservation. ${ }^{146}$ Courts should also consider the above guidelines in evaluating decisions by tribes to lease their water for off-reservation use. The following Section demonstrates that leasing Indian water to outsiders for off-reservation use can promote the purposes of Indian welfare and Indian economic self-sufficiency. Moreover, because the nation's market for buying and selling water rights has increased over the years, ${ }^{147}$ the leasing of Indian reserved water rights is a new pursuit consistent with the progress of civilization.

\section{III \\ OFF-RESERVATION LEASING ${ }^{148}$}

To date, no case or commentary has given significant attention to resolving the issue of leasing Indian water rights off the reservation. This Section argnes that off-reservation leasing of Indian water rights is con-

146. See United States v. Finch, 548 F.2d. 822, 830 (9th Cir. 1976) ("We need not, however, resolve this case solely by reference to the Treaty .... . [The court nayl interpret the terms of an Indian treaty in light of its history and the negotiations preceding it and to construe doubtful language in favor of the Indians."), vacated on other grounds, 433 U.S. 676 (1977).

147. See infra notes 221-20 and accompanying text.

148. The author would like to acknowledge and thank the John Muir Institute for Environmental Studies and the Ford Foundation for their support of the research effort underlying this section of the Coniment. 
sistent with the purpose of a reservation and the guidelines provided in Part II. This Section discusses the differing conclusions of commentators on the proper use of Indian water rights and how inconsistent interpretations of the overall intent of Congress in creating and maintaining an Indian reservation have produced opposing views. This Section then applies the principles developed above to determine whether a tribe can legally change its water use and proposes that Indian water rights should be considered a property right separable from the reservation lands. Finally, this Section discusses the benefits and risks to Indian tribes desiring to lease their water rights.

While Winters established that Indians have reserved water rights with a priority use, debate continues over the uses to which the Indian water can legitimately be put. ${ }^{149}$ Some argue that Indian water uses are determined solely by the agricultural needs of the reservation. ${ }^{150}$ Others insist that Indians can use their water for any purpose that promotes their "civilization," such as fishing, recreation, tourism, manufacturing, mining, the operation of a nuclear power plant, or any other activity, including off-reservation leasing of Indian water rights. ${ }^{151}$

In the context of the debate over the scope of Indian water rights, some commentators have likened Indian water rights to either the riparian or the appropriative systems of water law. These commentators conclude that the rules of transfer which apply to one system or the other should apply equally to the Indians. ${ }^{152}$ Applying the rules applicable to

149. See, e.g., Getches, Water Rights on Indian Allotments, 26 S.D.L. REv. 405 (1981) (concluding that no reserved rights may be individually held, but that during the period of trust some portion may be used by allottees); Leaphart, Sale and Lease of Indian Water Rights, 33 MoNT. L. REv. 266, 275 (1972) (Congress should provide for the leasing of reserved waters for use off the Indian reservation); Palına, Considerations and Conclusions Concerning the Transferability of Indian Water Rights, 20 NAT. RESOURCES J. 17 (1980) (arguing that the scope and extent of the reserved right is limited by the minimum quantity of water necessary to satisfy the purpose for which the reservation was created); Note, Transferability of Reserved Rights from the Indian Allottee to the Non-Indian Purchaser: Are the Purposes of the Reservation and the Interests of the Tribe Really Served? Colville Confederated Tribes v. Walton, 17 LAND \& WATER L. REV. 155 (1982) (focusing on the detrimental results of a transfer of an Indian allottee's reserved water rights to non-Indian purchaser); Recent Developments, Water Rights on Indian Reservations-Transferability of Indian Water Rights-State Administration of Non-Indian Water Rights Within the Reservation, 58 WASH. L. REV. 89 (1982) (argumg that unused reserved rights should be limited to Indians and that the state permit system should be used to administer nonreserved water rights on the reservation).

150. See, e.g., Palma, supra note 149, at 21; Palma, Indian Water Rights: $A$ State Perspective After Akin, 57 NeB. L. Rev. 295, 301-06 (1978); Pelcyger \& Bell, Indian Water Rights and the States: Looking from Both Sides, 6 STATE LEgisLATURES 20, $20-23$ (1980).

151. See, e.g., Leaphart, supra note 149, at 275-76 (arguing that Indian water rights should not be restricted to traditional agrarian and domestic purposes); Ranquist, supra note 9, at 658-59 (discussing arguments for all possible uses of Indian water rights to create viable Indian communities).

152. Compare F. COHEN, supra note 110, at 220 (explaining that Indian water rights are appurtenant to the lands), Leaphart, supra note 149, at 272-74 (arguing that Indian reserved rights exist independent of the land), and Meyers, The Colorado River, 19 STAN. L. REv. 1, 65-66, 68-69 
riparian water rights, Indian reserved rights could not be transferred from one parcel of land to another or removed from the watershed. Recall that under the riparian system, the water right is based on the ownership of land appurtenant to water. ${ }^{153}$ The appropriative water right, on the other hand, can be transferred, sold, and leased apart from the land. ${ }^{154}$

Jack Palma is a leading proponent of the view that Indian water rights exist as a result of land ownership, cannot be lost by nonuse, and thus are riparian in nature. ${ }^{155} \mathrm{He}$ reasons that the reservation of water in Winters was necessary to ensure that the lands would "support an agricultural use and a civilized lifestyle," 156 and therefore "[was] never intended to serve any function other than adding to the productivity of the reservation." ${ }^{157} \mathrm{He}$ concludes that off-reservation uses should not be allowed because the Indian rights "were created as an adjunct to land and have no existence apart from that land." 158

Indian water rights, however, were not "created as an adjunct to land," 159 but rather were created as an adjunct to congressional policy in establishing and maintaining Indian reservations. Congressional policy was aimed at encouraging Indian peoples to become tribally independent, industrious, and self-supporting American citizens. Congress intended to provide the Indians with the means to adopt American values, or the so-called "civilized life." Agricultural pursuits were merely one means by which Congress hoped to carry out that policy. Without water, the Indians could not develop toward a civilized life as intended by Congress. Hence, these rights relate less to the land than to congressional intent. ${ }^{160}$

Another scholar, Norris Hundley, has demonstrated the difficulties in applying the state appropriative and riparian laws to reservation lands. He discovered that Carl Rasch, an Assistant United States Attorney who acted on behalf of the Indians in Winters, knew that even though the Fort Belknap Indian Reservation abutted the Milk River, the riparian

(1966) (comparing Indian water rights to both the riparian and state appropriation water doctrines) with Palma, supra note 149, at 21 (asserting that Indian reserved rights are like the riparian systcm).

153. Recall that under the riparian system, the water right is based on the ownership of land appurtenant to water. See supra text accompanying notes 29-34.

154. 1 W. Hutchins supra note 28, at 476. In California Oregon Power Co. v. Beaver Portland Cement Co., 295 U.S. 142, 162 (1935), the Supreme Court found that appropriation laws had a "definite intention" to sever the land from the water in the public domain and directed that land be patented independent of any water rights. See supra notes 35-37 and accompanying text.

155. See Palma, supra note 149 , at 21.

156. Id. at 19.

157. Id. at 20 .

158. Id. at 19.

159. Id.

160. See Winters v. United States, 207 U.S. 564, 577 (1908); see also supra notes $54-55$ and accompanying text. 
doctrine "was an unpopular position in the arid West."161 Thus, Rasch understandably chose to emphasize the legally less offensive doctrine of appropriation." 162 But when Rasch learned that the non-Indian appropriators had begun diverting water froin the Milk River before the Indians had, he "abandoned the appropriation doctrine in favor of riparian law."163 Ultimately, the Winters Court did not rely upon either state law doctrine. Instead, the Court found that a right to water was implicitly reserved by the Fort Belknap Treaty for the benefit of the Indians. ${ }^{164}$

Not finding any express reservation of water in the treaty, the Winters Court concluded that the intent of Congress to change the noinadic habits of the Indians toward a civilized life could not be accomphished without water. ${ }^{165}$ Indian water rights were thus reserved for a use necessary to develop a civilized Indian society that would continue "through the years." 166 As an inplied treaty right, Indian water rights were not established as a unique extension of, or combination of, the state appropriative or riparian doctrines. The following Section discusses the appropriate applications, if any, of these doctrines to transfers of Indian water rights off the reservation. ${ }^{167}$

\section{A. Transfers of Indian Water Rights}

The transfer of Indian water rights either on or off the reservation raises two basic questions: First, to what extent may a tribe change its forn of water use, and second, what laws should govern the transfer of Indian water rights?

\section{On-Reservation Changes in Tribal Water Use}

In United States v. Anderson, ${ }^{168}$ the Eastern District of Washington discussed a tribe's right to change its type of water use on the reservation. The tribe in Anderson had sought to use its water rights, measured by the ainount currently being used for irrigation purposes, to inaintain a fishery. The court stated that reserved rights are based upon the primary purpose of the reservation, and reasoned that because the tribe's fishery was a primary purpose, water could be transferred from agricultural activities for that use. ${ }^{169}$ It is unclear whether the court intended to limit

161. Hundley, supra note 9 , at 24 .

162. Id.

163. Id. at 26 .

164. Id. at 26-27; see supra text accompanying notes $49-55$ (discussing the Supreme Court's interpretation of the Fort Belknap Treaty in Winters).

165. See supra notes $54-55$ and accompanying text.

166. Winters v. United States, 207 U.S. 564, 577 (1908).

167. See infra text accompanying notes $172-90$.

168. 591 F. Supp. 1 (E.D. Wash. 1982).

169. Id. at 7 . 
the transfer of Indian water rights to uses considered as primary at the time the reservation was created. Courts have already concluded, however, that non-Indians leasing Indian lands may use water for purposes not contemplated at the time of the reservation's creation. ${ }^{170}$ Thus, it would be anomalous for the Anderson court to have intended to prevent Indians from transferring water to certain uses merely because those uses were not expressly delineated in a treaty.

The opinion of the Anderson court supports allowing transfers of Indian water rights to new uses. The Anderson court stated that "[w] a Tribe has a vested property right in reserved water, it may use it in any lawful manner."171 The use of a quantified Indian water right "in any lawful manner" would be consistent with the guidelines established in Part II of this Comment. Under those guidelmes, any reasonable and beneficial water use that promotes the tribal economy or tribal welfare is permissible. A change from one permissible water use to another then, would be consistent with the reservation's purpose.

\section{Laws Governing the Transfer of Water Rights}

Since Indian water rights exist as a treaty right, they are by definition not subject to the same rules or procedures that govern the appropriative or riparian doctrines. ${ }^{172}$ Nevertheless, Indian reserved water rights have characteristics of both the appropriative and riparian systems. Like the riparian system, Indian reserved rights are not lost by nonuse. ${ }^{173}$ Yet, riparian rights exist as an incident to land ownership, ${ }^{174}$ and Indian reserved rights were created to fulfill the intent of Congress in establishing and maintaiming reservation lands. Since Indian water rights are not based on land ownership but rather on congressional intent, the rules of transfer that apply to riparian lands are inappropriate with respect to water transfers off reservation lands.

On the other hand, the majority of reservation lands are located in states following the appropriation doctrine. ${ }^{175}$ While this suggests an mherent conflict, Indian water rights can be reconciled somewhat with appropriation laws. This is because Indian water rights are similar to the appropriation doctrine in that they are subject to quantification and have a priority, or "first right," dating from the creation of the reservation. ${ }^{176}$ Similarly, state appropriation laws prioritize water rights by date of the

170. See supra note 18 ; see also infra note 222 and accompanying text.

171. Anderson, 591 F. Supp. at 7.

172. Cf. Cappaert v. United States, 426 U.S. 128, 145 (1976) ("Federal water rights are not dependent upon state law or state procedures").

173. See supra notes $33 \& 40$ and accompanying text.

174. See supra note 33 and accompanying text.

175. See supra note 41 and accompanying text.

176. Winters v. United States, 207 U.S. 564, 577 (1908). 
first beneficial diversion. ${ }^{177}$ Thus, priority of right in an arid environinent is an essential element for both the reserved rights doctrine and the appropriation system. ${ }^{178}$ Moreover, both state appropriation rights and reserved rights appear to be separable from the land. The appropriation system developed because of the need for water on arid lands, or lands not appurtenant to a water source. ${ }^{179}$ An appropriative right therefore is considered a separate property right which can be transferred, sold, or leased apart from the land. Because a majority of reservation lands are situated in arid regions as well, courts have recognized the need for water transfers and have begun to characterize Indian water rights as property rights separable froin the land. ${ }^{180}$

The notion that Indian water rights are vested property rights was first expressed by the Special Master in Arizona v. California. ${ }^{181}$ The Master stated that his decree "establishes a property right which the United States may utilize or dispose of for the benefit of the Indians." 182 By characterizing Indian water rights as property rights with a fixed quantity and priority, the Master encouraged a marketing concept whereby the tribe could transfer, lease, or sell their rights if the federal government agreed. ${ }^{183}$ The Supreme Court in Arizona v. California implicitly validated the concept of Indian water as a property right separable from the land by awarding Colorado River water for use on two nonriparian tracts belonging to the Cocopah Indian Reservation. ${ }^{184}$ Thus, the Court necessarily viewed the Indian water right as a right separate from the land because it awarded to the Cocopah Indian Reservation water which did not originate on, under, or flow adjacent to the reservation lands.

Likewise in United States $v$. Anderson, ${ }^{185}$ the court referred to the Indian water right as a "vested property right."186 Once quantified, the court indicated that the Indian water right nay be transferred to new

177. See supra note 40 and accompanying text.

178. See supra notes $35-36$ and accompanying text.

179. Id.

180. Arizona v. California, 373 U.S. 546 (1962).

181. Id. In United States v. Ahtanum Irrigation Dist., the Ninth Circuit took an early step in developing such a view by implying that Indian water rights are not limited to the waters and water sources that originate or are physically located on the property of their owner. $236 \mathrm{~F} .2 \mathrm{~d} \mathrm{321,325}$ (9th Cir. 1956), cert. denied, 352 U.S. 988 (1957).

182. Report of Special Master Rifkind 266, Arizona v. California, 373 U.S. 546 (1963).

183. See id. at 265-66; see also Meyers, supra note 152, at 71 (noting that the Master had encouraged the selling and leasing of Indian water rights by inviting attention to three essential characteristics of a marketable property right: freedom of transfer, freedom of use, and quantification). Note that the transfer of Indian water rights may require congressional approval. See infra note 208 and accompanying text.

184. 373 U.S. at $595-96,601$.

185. 591 F. Supp. 1 (E.D. Wash. 1982).

186. Id. at 7. 
uses in any lawful manner. One "lawful manner" might be to lease water off the reservation in a manner consistent with transfers of appropriative rights. The primary limitation on transfers of appropriative rights are that they must meet the requirements of reasonable and beneficial use, ${ }^{187}$ and no injury can result to junior appropriators relying on previously established return flows. ${ }^{188}$

Although tribes can pass laws governing the reasonable and beneficial use of their water leased to non-Indians for off-reservation use, it is possible that tribal rules defining what constitutes a reasonable and beneficial use will differ from state law. To prevent confusion and waste, and to promote uniform and consistent standards that benefit both Indians and non-Indians alike, courts should construe regulations governing the use of Indian water transferred of the reservation in accordance with state law. ${ }^{189}$ Since water is the critical limiting factor to the continued vitality and future development in the arid West, ${ }^{190}$ off-reservation transfers of Indian water rights should be permitted only where there is no significant injury to junior appropriators.

In Colville Confederated Tribes v. Walton, ${ }^{191}$ the Ninth Circuit Court of Appeals considered whether a state has authority to grant and regulate water permits to non-Indians using Indian water rights within the reservation's boundary. In Colville, the court rejected the state's claim. ${ }^{192}$ The court concluded that "regulation of water on a reservation is critical to the hifestyle of [tribal] residents and the developnient of [tribal] resources," and thus, tribal control over on-reservation uses of Indian water rights is an "inportant sovereign power."193

Colville concerned waters located entirely within the reservation's boundary. ${ }^{194}$ The court specifically noted that this fact made "resolution of this issue soniewhat easier than it otherwise might be"195 because tribal control of the water use "ha[d] no impact off the reservation." 196 In concluding that state water laws are not controlling on an Indian reservation, ${ }^{197}$ the court strongly implied that where Indian control of reserved

187. See supra note 32 .

188. $1 \mathrm{~W}$. HuTCHINS, supra note 28 , at 476,631 .

189. See supra note 6 and accompanying text. Regulatory powers and tribal jurisdiction over their natural resources involve sovereignty issues beyond the scope of this Comment. See supra note 109 and sources cited therein; see also Amundson, Recent Judicial Decisions Involving Indian Water Rights, in 3 INDIAN WATER 1985 17-19 (C. Miklas \& S. Shupe eds. 1986) (discussing case law relevant to tribal regulation of water rights on the reservation).

190. See supra notes 2-3 and accompanying text.

191. 647 F.2d 42 (9th Cir.), cert. denied, 454 U.S. 1092 (1981).

192. Id. at 51 .

193. Id. at 52 .

194. Id.

195. Id.

196. Id. at 53 (emphasis added).

197. Id. (citing United States v. McIntire, 101 F.2d 650, 654 (9th Cir. 1934)). 
rights affects off-reservation rights, or where "legal confusion ... . would arise if federal water law and state water law reigned side by side in the same locality,"198 then state law should govern. Obviously, unregulated off-reservation transfers of Indian water rights could dramatically affect water rights estabhished pursuant to state law. ${ }^{199}$ Likewise, conflicting tribal and state rules could result in precisely the type of "legal confusion" referred to by the court. Thus Colville suggests that off-reservation transfers of Indian water rights could be regulated by state appropriation laws.

Once transferred, state regulation of Indian water rights used off the reservation will promote certainty of rights for current and future nonIndian development. Uniform state rules that define what is reasonable and beneficial for off-reservation water use will avoid confusion and waste. Moreover, state regulation of off-reservation Indian water leases will not impair the right of reservation Indians to govern their lands, nor will it destroy the essential characteristics of Indian reserved rights. Priority of right will still date from the reservation's creation, and Indian water rights will not be lost by non-use. If a non-Indian user of the transfered right fails to put the water to a reasonable and beneficial use as defined by state law, the water right will simply revert to tribal control.

Reconciling the transfer of appropriative and Indian reserved rights also would further the government's overall policy toward Indian tribes and would be consistent with the guidelines developed in Part II of this Comment. Allowing Indians to market their water as a property right separate from the reservation land would promote the American value of ownership of private property. Recoguizing that this activity will encourage economic self-sufficiency and promote the ways of civilized life, recent federal policies support the alienation of Indian water rights for off-reservation use. Like past federal Indian policies, the current policy encourages water uses, whetlier on or off the reservation, for the purpose of creating viable Indian economies and furthering tribal selfsufficiency.

\section{B. Current Government Policy Regarding Off-Reservation Leases}

Many of the arguments supporting or opposing the marketing of Indian water rights for off-reservation use have been noted by the federal government, and, in particular, by the Water Policy Advisory Group in the Department of the Interior. In a recent letter to the Executive Director of the Association of California Water Agencies, ${ }^{200}$ the Solicitor wlio

198. Id. at 52 (citing California v. United States, 438 U.S. 645, 653-54, $668-69$ (1978)).

199. See infra text accompanying note 213.

200. Letter from William Coldiron, Office of the Solicitor, United States Dep't of the Interior to John Fraser, Executive Director, General Counsel, Association of California Water Agencies (Mar. 
oversees this group outlined the Department's position concerning the inarketing of Indian water rights. ${ }^{201}$ The Solicitor first addressed opposition based on fear that unlimited marketing of Indian water by lease and conveyance would disrupt quantification efforts in the arid West. ${ }^{202}$ The Solicitor explained that Winters rights would be quantified only in "amounts necessary to fulfill the purposes of the reservation to which they pertain" and no excess Winters rights would be asserted "simply because there might exist a market for that off the reservation." 203 In other words, the government will not argue on behalf of Indian tribes for water riglits in excess of a quantity measured by practicably irrigable acres and minimuin instreain flows solely because a local industry or muricipality is interested in leasing tle right.

The Solicitor continued that once the Indian water riglits are quantified, Winters riglits slould not be restricted to any particular beneficial use. He outlined two policy reasons for this view. First, beneficial use of Indian water both on and off the reservation "is consistent with President Reagan's efforts to strengtlien tribal economies and governinents by giving the Indians inore control over and benefits from their natural resources." 204 The Solicitor noted that the marketing of Indian water rights could generate substantial incoine for the Indians, and provide the tribes witl "needed flexibility in their resource developinent planning."205 Second, off-reservation use of Indian water can be a "valuable tool" in negotiating the settleinent of disputes over Indian water rights. For exainple, one settlement provided for off-reservation marketing because the parties realized that transferring Indian water riglits in water short areas would serve both the Indians' and the otler regional users' econoinic interests. ${ }^{206}$ In addition, the Solicitor found "no insuperable legal bar to n1arketing of Indian water rights off the reservation."207 While the alienation of Indian property without congressional approval is prohibited by the Nonintercourse Act, ${ }^{208}$ the Solicitor noted that such

29, 1983) reprinted in Office of the Solicitor, U.S. Dep't of the Interior, Memorandum for the Water Policy Advisory Group (Oct. 22, 1984) [hereinafter Solicitor Letter] (copy on file with author).

201. The letter was written "not for the purpose of ending debate, but to express what appear to us to be good reasons in support of off-reservation marketing." Id.

202. This concern has been expressed elsewhere. See, e.g., Note, A Proposal for the Quantification of Reserved Indian Water Rights, 74 CoLUM. L. REv. 1299, 1318 (1974).

203. Solicitor Letter, supra note 200.

204. Id.

205. Id.

206. See Colorado Ute Indian Rights Settlement Act of 1987, S. Res. 1415, 100th Cong., 1st Sess., 133 CONG. REC. $§ 8589-91$ (1987).

207. Solicitor Letter, supra note 200.

208. 25 U.S.C. $\$ 177$ (1982), which provides in relevant part: "No purchase, grant, lease, or other conveyance of lands, or of any title or claim thereto, from any Indian nation or tribe of Indians, shall be of any validity in law or equity, unless the same be made by treaty or convention entered into pursuant to the Constitution." In statutes of this nature, the word "land" has been 
approval can be obtained from Congress at any time. ${ }^{209}$ Thus, the Solicitor's letter indicates that the government, eager to promote its recurrent policy in favor of Indian self-determination and Indian economic selfsufficiency, supports Indian water leasing programs.

\section{Policy Arguments Relating to Off-Reservation Use}

Although recent decisions have permitted tribes to change the onreservation use of their water ${ }^{210}$ and have begun to characterize Indian water rights as transferable property rights, ${ }^{211}$ commentators continue to discuss the policy arguments of off-reservation leases of Indian water rights. This Comment asserts that those arguments opposing Indian water leases off the reservation are either based on an erroneous understanding of a reservation's purpose, ${ }^{212}$ or are outweighed by the benefits of such leases to Indians and non-Indians alike.

Scholars who argue against off-reservation leases are concerned about Indian water uses that could disrupt the current status of nonIndian water users. Palma has argued:

The transfer of Indian water rights for off-reservation uses can only heighten the apprehension within western states, since it will greatly increase the prospect that large quantities of water will be consumptively used by Indian water right holders to the exclusion of vested appropriators. Such exploitation of these Indian water rights by sale or lease to others for use off the reservation would surely have a devastating effect upon the non-Indian economy. ${ }^{213}$

These claims are erroneous for two reasons. First, as the Solicitor's statement indicates, Indian water rights will not be quantified for leasing purposes simply because a market exists. ${ }^{214}$ The Supreme Court has already adopted the primary means of quantifying Indian water rights

construed to include appurtenant waters. See Holmes v. United States, 53 F.2d 960, 963 (10th Cir. 1931); North Side Canal Co. v. Twin Falls Canal Co., 12 F.2d 311, 314 (D. Idaho 1926). Thus, it is likely that conveyances of Indian water rights will require congressional approval. Note, however, that Indian lands may be leased for certain purposes with the approval of only the Secretary of the Interior. 25 U.S.C. $\S 415$ (1982); see United States v. Ahtanum Irrigation Dist., 236 F.2d 321, 33537 (9th Cir. 1956) (Secretary of the Interior can divide waters of streams bordering reservations between Indians and non-Indian settlers because Congress delegated this authority when it gave the Secretary supervisory and management power over Indian affairs), cert. denied, 352 U.S. 988 (1957).

209. Solicitor Letter, supra note 200.

210. See supra notes $169-71$ and accompanying text (discussing United States v. Anderson, 591 F. Supp I (E.D. Wash. 1982)); see also Report of Special Master Rifkind 265-66, Arizona v. California, 373 U.S. 546 (1963) ("The measurement used in defining the magnitude of the water rights is the amount of water necessary for agricultural and related purposes because this was the initial purpose of the reservations, but the decree establishes a property right which the United States may utilize or dispose of for the benefit of the Indians as the relevant law may allow.")

211. See supra notes 181-99 and accompanying text.

212. See supra text accompanying notes $155-58$.

213. Palma, supra note 149 , at 21 .

214. See supra note 152 and accompanying text. 
according to "practicably irrigable acreage."215 The Court has further stated that Indian treaty rights to a natural resource "secures so much as, but not more than, is necessary to provide the Indians with a livelihood-that is to say, a moderate living."216 Thus, there is a clear limit to the quantity of water rights available to the tribes.

Second, the potential for disrupting established use patterns is no greater with respect to off-reservation uses than for on-reservation use. ${ }^{217}$ Arguably, limiting Indian water use to the reservation will not significantly lessen the effect on established or prospective non-Indian uses once tribes find ways to more fully develop their on-reservation water uses. In fact, if off-reservation leases of Indian water rights are regulated by state law, ${ }^{218}$ then existing rights will not be jeopardized to any greater degree than ordinary transfers under state law. Junior appropriators could still rely on return flow. ${ }^{219}$

Most importantly, off-reservation leasing can produce the most beneficial use of water for Indians and non-Indians alike. Given the West's inadequate water resources, it can be assumed that a inarket exists for the transfer of Indian water rights for uses both on and off the reservation. Transfers on or off the reservation would assist the development of Indian society not only through agriculture, but also through other "arts of civihzation."220 Non-Indians would likely pay siguificant amounts to acquire a valuable reservation priority date. ${ }^{221}$ In turn, non-Indian economies would benefit through the emergence and expansion of ventures that will exploit the leased rights. By contrast, denying off-reservation leases wonld constrain Indian econounic developinent and inhibit efficient water and land use manageinent in a thirsty environinent.

The existing practice of tribes leasing reservation lands for use by non-Indians provides support for the argument that off-reservation leasing of Indian water will aid local Indian econoinies. For instance, in

\footnotetext{
215. Arizona v. California, 373 U.S. 546, 600 (1963); see also supra note 64.
}

216. Washington v. Fishing Vessel Ass'n, 443 U.S. 658, 686 (1979).

217. Ranquist, The Effect of Changes in Place and Nature of Use of Indian Rights to Water Reserved Under the 'Winters Doctrine,' 5 NAT. REsourCES J. 34, 40-41 (1972). A similar argument is that off-reservation water leases will disrupt the state appropriation system by allowing tribes to transfer their priority to water users who would not otherwise have such a priority. See Palma, supra note 149, at 257. Apparently, permitting junior appropriators, who acquire rights later in time, to receive a reservation priority date is unfair to senior appropriators. This, however, is the very nature of the appropriation system. Senior appropriators, subject to change in place and use requirements, can generally transfer their rights to juniors who would not otherwise have an earlier priority date. See WATER POLICIES, supra note 5, at 260.

218. See discussion accompanying notes 187-99.

219. 1 W. HuTCHINS, supra note 28 , at 476,631 .

220. Winters v. United States, 207 U.S. 564, 576 (1908).

221. See INDIAN WATER POLICY, supra note 33, at 102 (in various parts of the West, "[w]ater may be selling for $\$ 100$ to $\$ 200$ an acre-foot in some basins, and may have gone up steeply, ... selling for as much as $\$ 10,000$ or $\$ 11,000$ an acre-foot"). 
1973, the leasing of Indian lands for agricultural, business, and recreational purposes resulted in an income of nearly $\$ 28$ million. ${ }^{222}$ In addition to the direct financial benefit that would result from transferring Indian water rights in a water-scarce environment, ${ }^{223}$ the marketing of Indian water rights would generate jobs, ${ }^{224}$ increase services, and stimulate the economic growth of the reservation as a whole. ${ }^{225}$

Off-reservation leasing is a particularly attractive method of spurring Indian economic development because it is unaffected by the complicated cultural and geographical differences that exist between reservations. Reservations vary in "such factors as proximity to major economic centers, general accessibility, climate, availability of exploitable natural resources, size and composition of labor force, manual skills of the labor force, entrepreneurial skills, attitudes toward economic development, availability of capital and financial assistance, stabihity and commitment of tribal leadership."226 These cultural variations make traditional means of economic development comphcated, whereas off-reservation leasing is not complicated by these cultural factors. ${ }^{227}$

In some instances, leasing may be the tribe's only opportunity to develop the reservation economy. ${ }^{228}$ If the reservation lands are very poor in quality, the only profitable use of an Indian water right may be in marketing it off the reservation. ${ }^{229}$ Even if the reservation lands are agriculturally viable, Indian irrigation projects are frequently underfunded by the government ${ }^{230}$ and Indians generally do not have the capital required to construct full irrigation projects themselves. ${ }^{231}$ At a minimum, tribes should be permitted to lease part of their water rights in

222. Chambers \& Price, supre note 18, at 1063.

223. See supra note 221.

224. Unemployment on Indian reservations averages $50 \%$, with rates on some reservations exceeding $80 \%$. Those who do find work are often underemployed and earn scant wages. In addition, the average Indian income is below $\$ 2,000$ per year and only ten percent of Indian families have annual incomes exceeding \$5,000. See ECONOMIC DEVELOPMENT ADMIN., U.S. DEP'T OF COMMERCE, INDIAN ECONOMIC DEVELOPMENT: AN EVALUATION OF EDA'S SELECTEd INDIAN Reservation Program 12 (1972) [hereinafter Indian Economic DeVelopment].

225. M. Price \& R. Clinton, LAW and the AMERiCAN Indian 736 (2d ed. 1983).

226. INDIAN ECONOMIC DEVELOPMENT, supra note 224, at 12.

227. See infra note 233 and accoinpanying text.

228. See Note, Indian Reserved Water Rights: The Winters of Our Discontent, 88 YALE L.J. 1689,1701 (1979) (noting that this is especially true where Indian reserved rights reinain unused due to the tribes' inability to finance development).

229. Note, supra note 202, at 1317; see also Moore v. United States, 157 F.2d 760, 762 (9th Cir. 1946) (reservation in question consisted of about 500 acres of poor land covered with trees and not suited for agriculture).

230. See Comment, The Water Rights of Klamath Indian Allottees, 59 OR. L. REv. 299, 317 n.93 (1980); see also WATER Policies, supra note 5, at 479 ("In the history of the United States Governments' treatinent of Indian tribes, its failure to protect Indian water rights for use on the reservations it set aside for thein is one of the sorrier chapters.").

231. Coininent, supra note 230 , at 317 n.93. 
order to gain capital to develop the remaining land. ${ }^{232}$

\section{Social Impact Upon Tribes Choosing to Lease Their Water Rights}

Although this Comment supports the legal permissibility of off-reservation leasing of Indian water rights, it recognizes that leasing might have some adverse effects on tribal culture and pohtical sovereignty. For example, off-reservation water leases could potentially divert inore capital off the reservation than the incoine generated from the lease. With the option of leasing Indian water for off-reservation use, non-Indians will not be encouraged to bring their investments and related water needs to the reservation itself. Incoine, jobs, and economic growth on the reservation are miportant to those tribes otherwise lacking the capital to develop their lands. As with any on-reservation developinent, however, there is soine risk that non-Indians will fill job openings on the reservation and threaten cultural stability. ${ }^{233}$ Moreover, on-reservation leasing and development inay create an "increased appetite by state governments to regulate and control Indian land use."234 In the long-run, increased state regulation could interfere with the "lawmaking power of the tribe and its cultural and pohitical future [as well as with its] control over the reservation." $" 235$

Off-reservation leases are not likely to create these same cultural and pohtical concerns simply because they will not encourage non-Indians onto the reservation. The tribes may derive substantial income froin offreservation leases, and thus, regardless of the existence of potentially negative effects, the decision to lease their water rights should rest with the tribes. Price and Clinton have expressed concern that although the lease will provide a short-term source of incoine for the Indians which could at some point be used to develop on-reservation irrigation projects, the Indians may lose their long terin water rights to non-Indians who have acquired vested economic interests pursuant to their lease. ${ }^{236}$ Similarly,

232. See id. at 324 (the sale of a portion of an Indian allottee's land in order to agrieulturally develop his remaining land should be permitted as consistent with the agricultural purposes of the reservation). Other commentators have noted that where there are imsufficient funds to develop onreservation water uses, "the denial of the Indians' right to lease or assign water rights to offreservation users would be particularly harmful." DuMars \& Ingram, Congressional Quantification of Indian Reserved Water Rights: A Definitive Solution or a Mirage?, 20 NAT. Resources J. 17, 31 (1980). They argue that "[i]t would deny the tribes the use of a property interest and deprive them of needed income for economic enrichment programs. It may ultimately prevent the watcr from ever being put to its maximum beneficial use because of lack of capital." Id. In order to promote a self-determination policy goal, the authors argue that the Indians should be able to use their water upon federal approval however they wish. Id.

233. See, e.g., Chambers \& Price, supra note 18, at 1064.

234. Id. at 1065-1067 \& n.25.

235. Id. at 1064 .

236. M. PRICE \& R. Clinton, supra note 225 , at 717 . 
converting water use back from non-Indian agriculture to Indian agriculture may be prohibitively expensive, leaving Indians with only the income generated from their lease. ${ }^{237}$ But, as with any contractual agreement, terms may be adjusted or other judicial remedies may be available to the tribe. Moreover, before the lease expires, tribes will be free to renegotiate the terms and receive additional compensation from the lease.

\section{IV \\ CONCLUSION}

This Comment addresses the need for a proper understanding of the purpose of an Indian reservation. Without clear directives, courts can err in ascertaining the permissible extent of Indian water uses. Based on historical Federal-Indian relations, this Comment provides guidelines to help determine whether specific Indian water uses are consistent with the reservation's purpose.

This Comment sliows that one contemplated use-off-reservation leasing of Indian water riglits-thougli controversial, is consistent with past and current governmental policy and is a legitimate use of reserved rights. Moreover, off-reservation leasing is consistent witl the purposes of a reservation recognized by the United States Supreme Court in Winters v. United States, ${ }^{238}$ Alaska Pacific Fisheries v. United States, ${ }^{239}$ Arizona v. California, ${ }^{240}$ and in otlier cases decided by the Nimth Circuit Court of Appeals. ${ }^{241}$ The Supreme Court has not ruled on the legality of changing water use on the reservation, nor lias it considered whether Indian water riglits are separable from the land. Thus the only legal barrier to off-reservation leasing is the Nonintercourse Act, ${ }^{242}$ which mandates federal approval of certain Indian transactions.

Althougli there are objections to-and concerns about-off-reservation leasing of Indian water riglits, these leases offer benefits to both the tribes and non-Indian entities. Water means wealth, power, and life, especially in the arid regions of the country, and the unrelenting demand and imcreasing competition over the limited water supply contmues. Offreservation leasing will bring needed capital to the reservation while satisfying non-Indian demands for water. Clearly, tribes inust confront difficult issues in deciding whether to transfer their water riglits eitlier on or off the reservation. However, those clioices inust be left to the tribes. To

237. See id.

238. 207 U.S. 564 (1908).

239. 248 U.S. 78 (1918).

240. 373 U.S. 546 (1963).

241. See cases discussed supra notes 68-76.

242. 25 U.S.C. $\S 415$ (1982). 
deny Indians the opportunity to choose among means for developing their society in the way most suited to their needs would be to reject the very intent of Congress in establishing and maintaining Indian reservations.

Lee Herold Storey*

* B.A. 1982, University of California, Los Angeles; M.A. 1984, University of California, Los Angeles; J.D. 1987, Boalt Hall School of Law, University of California, Berkeley. Associate, Evans, Kitchel \& Jenckes, P.C. 